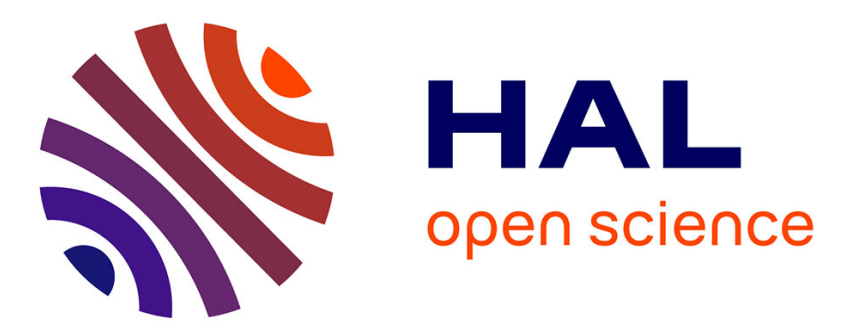

\title{
A simple model to estimate exchange rates of nitrogen dioxide between the atmosphere and forests
}

\author{
J. Duyzer, K. Pilegaard, D. Simpson, H. Weststrate, S. Walton
}

\section{To cite this version:}

J. Duyzer, K. Pilegaard, D. Simpson, H. Weststrate, S. Walton. A simple model to estimate exchange rates of nitrogen dioxide between the atmosphere and forests. Biogeosciences Discussions, 2005, 2 (4), pp.1033-1065. hal-00297787

\section{HAL Id: hal-00297787 \\ https://hal.science/hal-00297787}

Submitted on 17 Aug 2005

HAL is a multi-disciplinary open access archive for the deposit and dissemination of scientific research documents, whether they are published or not. The documents may come from teaching and research institutions in France or abroad, or from public or private research centers.
L'archive ouverte pluridisciplinaire HAL, est destinée au dépôt et à la diffusion de documents scientifiques de niveau recherche, publiés ou non, émanant des établissements d'enseignement et de recherche français ou étrangers, des laboratoires publics ou privés. 
A simple model for air-forest exchange of $\mathrm{NO}_{\mathbf{x}}$ and $\mathrm{O}_{3}$

J. Duyzer et al.

\section{A simple model to estimate exchange rates of nitrogen dioxide between the atmosphere and forests}

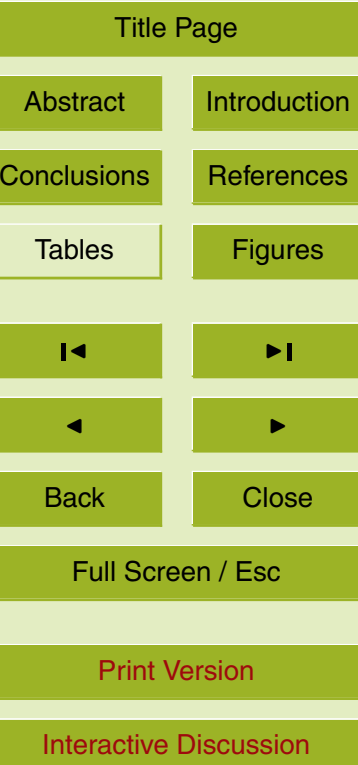

J. Duyzer ${ }^{1}$, K. Pilegaard ${ }^{4}$, D. Simpson ${ }^{2}$, H. Weststrate ${ }^{1}$, and S. Walton ${ }^{3}$

${ }^{1}$ TNO Institute of Environmental Sciences, Laan van Westenenk 501, Apeldoorn, The Netherlands

${ }^{2}$ Norwegian Meteorological Institute, Oslo, Norway

${ }^{3}$ Deceased. Physics Department, UMIST, Manchester, UK

${ }^{4}$ Risoe National Laboratory, Roskilde, Denmark

Received: 5 July 2005 - Accepted: 22 July 2005 - Published: 17 August 2005

Correspondence to: J. Duyzer (duyzer@mep.tno.nl)

(C) 2005 Author(s). This work is licensed under a Creative Commons License. 


\section{Abstract}

A simple model (2layer) was constructed that describes the exchange of the reactive gases $\mathrm{NO}, \mathrm{NO}_{2}$ and $\mathrm{O}_{3}$ between forest and the atmosphere. The model uses standard equations to describe exchange processes and uptake of gases. It also takes into

5 account reactions taking place in the trunk space between $\mathrm{NO}$ and $\mathrm{O}_{3}$ and photolysis of $\mathrm{NO}_{2}$. All equations are solved analytically leading to a scheme efficient enough to allow implementation in a large scale dispersion model such as the EMEP model.

The model is tested on two comprehensive datasets obtained in a coniferous forest and a deciduous forest. The model calculations of $\mathrm{NO}_{2}$ and $\mathrm{O}_{3}$ fluxes to the forest were compared with observations of these fluxes. Although the comparison is often not perfect some of the striking features of the observed fluxes i.e. upward fluxes of $\mathrm{NO}_{2}$ were simulated quite well. The impact of chemical reactions between $\mathrm{O}_{3}$, $\mathrm{NO}$ and $\mathrm{NO}_{2}$ in the trunk space appear to have a significant effect on the deposition rate of $\mathrm{O}_{3}$. This is especially true during the night and more so for forests emitting large amounts 15 of NO.

\section{Introduction}

Ozone $\left(\mathrm{O}_{3}\right)$ and nitrogen oxides (nitric oxide and nitrogen dioxide; $\mathrm{NO}_{\mathrm{x}}$ ) are key elements in tropospheric chemistry. They are associated with environmental issues such as forest dieback, eutrophication and the greenhouse effect. To define optimal strategies to reduce the environmental effects of these gases quantitative knowledge on production and loss processes of these gases is required. For ozone the uptake at the earth surface (dry deposition) is the most important loss process. For nitrogen oxides other loss processes are more important. It is however still very important to have quantitative knowledge on the dry deposition rates of these gases. This knowledge is important in order to estimate the input of gases contributing to acidification and eutrophication of sensitive ecosystems such as forests. The knowledge on exchange
BGD

2, 1033-1065, 2005

A simple model for air-forest exchange of $\mathrm{NO}_{\mathbf{x}}$ and $\mathrm{O}_{3}$

J. Duyzer et al.

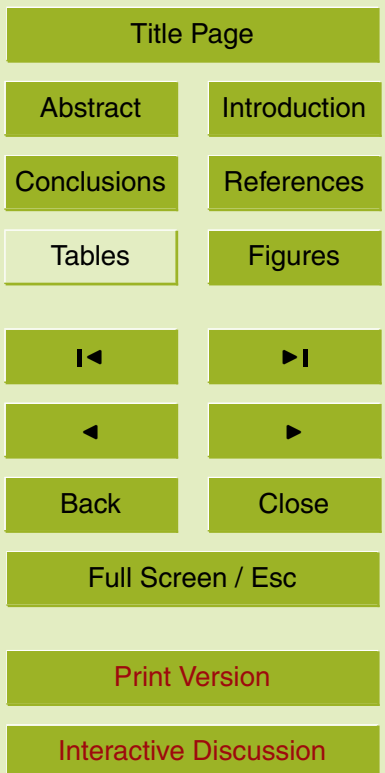

EGU 
rates of these gases is however, in general, very limited. Especially for nitrogen-oxides information is scarce.

Measurements using micrometeorological methods have shown rather confusing results (Walton et al., 1997; Coe and Gallagher, 1992; Hicks et al., 1989, 1986, 1983).

5 Some of these results could be related to classical problems such as noisy instruments, advection etc. During the last few years measurement methods have been improved and there is a growing evidence that there are other causes processes causing the unexpected observations (Duyzer et al., 1996). These may be related to rapid reactions taking place in the atmosphere between the observation height and the surface.

10 Especially the reactions between nitric oxide (NO) and ozone $\left(\mathrm{O}_{3}\right)$ and the photolysis of nitrogen dioxide $\left(\mathrm{NO}_{2}\right)$ are fast enough to interfere with turbulent transport. This effect has been recognised for several years now (Duyzer et al., 1983; Fitzjarrald and Lenshow, 1983). Procedures to correct observations for these reactions have been described in literature (Kramm et al., 1991; Galmarini et al., 1997). Above forest the 15 situation could be even more complex. Atmospheric turbulence above may be intense but the intermittent exchange between the atmosphere and the space below the canopy (the trunk space) could create larger time scales. Air parcels entering the forest from the atmosphere could remain in the trunk space long enough to allow chemical processes to change their composition.

20 Detailed models have been constructed which are able to explain some of the phenomena observed above forests (Gao et al., 1991; Duyzer et al., 1995). These models have shown to be able do explain many of the observations of $\mathrm{NO}_{2}$ fluxes above forests quite well (Walton et al., 1997a, b; Duyzer et al., 1996).

The drawback of these complex models is the need for very detailed information 25 on forest parameters and their large use of computer resources. The mathematical methods that these models use to solve the set of coupled differential equations often make them less useful in large dispersion models. Therefore our aim was to develop a model that would be simple enough to be incorporated in a large scale air pollution dispersion model such as the EMEP model (Simpson et al., 2003). The structure of

BGD

2, 1033-1065, 2005

\section{A simple model for air-forest exchange of $\mathrm{NO}_{\mathbf{x}}$ and $\mathrm{O}_{3}$}

J. Duyzer et al.

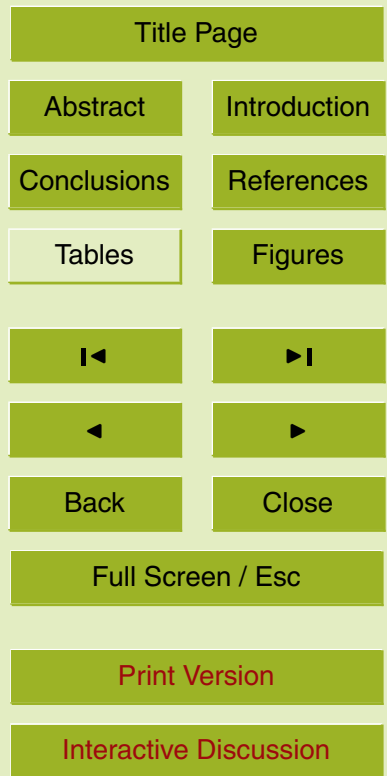

EGU 
the model structure is strongly related to the well known resistance layer model (see for example Baldocchi et al., 1987) This makes the model easy to implement in other models and studies.

In this paper we will describe the model ("2layer") and compare the results of calcu5 lations with the model with experimental results.

\section{Description of the model}

The model derived here uses two conceptual layers or zones. The top layer simulates the crown level in the forest whereas the lowest level simulates the trunk space. Concentrations of gases in atmosphere (at the measurement level) have subscript "air" and

10 "trunk" (the trunkspace i.e. the level below the crown).

Figure 1 provides an overview of the processes and resistances accounted for in the model. $R_{a}, R_{b}$ and $R_{c}$ are the aerodynamic resistance, boundary layer and canopy resistance. $C_{\text {leaf }}$ represents the concentration in the canopy at the leaf surface. Note that the left hand side of the figure represents the classical, simple, resistance layer model.

15 The right hand side represents the transport into the trunk space where $R_{x}$ represents the resistance to transport through the crown from the leaf surface to the trunk-space where the concentration is equal to $C_{\text {trunk }}$. In the trunk space chemical reactions take place between nitrogen oxides and ozone, transported from the atmosphere and emitted from soil. Only three gases are considered: $\mathrm{NO}, \mathrm{NO}_{2}$ and $\mathrm{O}_{3}$. These may undergo the following reactions: $\mathrm{NO}+\mathrm{O}_{3}=\mathrm{NO}_{2}$ with a rate constant $k_{1} . \mathrm{NO}_{2}+h v=\mathrm{NO}$ with a rate constant $j_{\mathrm{NO}_{2}}$; the photolysis rate of $\mathrm{NO}_{2}$ above the canopy. $\mathrm{NO}_{2}$ photolysis taking place below the canopy is assumed to proceed at a slower rate than given by $j_{\mathrm{NO}_{2}}$.

This implies that we thereby, at this time, ignore other, slower, reactions and reactions at other levels ${ }^{1}$. This seems reasonable since the two reactions above are very fast and therefore the most relevant for the studied compounds. Turbulent timescales are

\footnotetext{
${ }^{1}$ Although biogenic VOC have been shown to play a critical role in ozone fluxes in a study in California (Goldstein et al., 2004) there is little evidence for such large contributions in Euro-
}

\section{BGD}

2, 1033-1065, 2005

\section{A simple model for air-forest exchange of $\mathrm{NO}_{\mathbf{x}}$ and $\mathrm{O}_{3}$}

J. Duyzer et al.

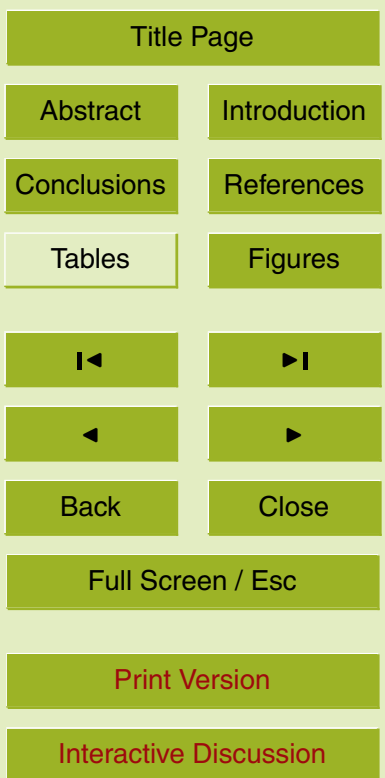

EGU 
much smaller above the forest and therefore chemical reactions have less impact. Also model calculations by Duyzer et al. (2004) have shown little flux divergence above the forest.

In the trunk space deposition to leaves of the plants growing on the forest floor 5 (the under storey) is also accounted for. The following equations describe the various fluxes: The flux from the atmosphere into the forest is the sum of the fluxes to the leafs and the flux to the trunk-space. Applying the resistance analogy the flux is equal to the concentration difference between the atmosphere and the leaf level divided by the aerodynamic resistance:

2, 1033-1065, 2005

\section{A simple model for air-forest exchange of $\mathrm{NO}_{x}$ and $\mathrm{O}_{3}$}

J. Duyzer et al.

$F_{\text {total }}=F_{\text {leaf }}+F_{\text {trunk }}=\frac{-\left(C_{\text {air }}-C_{\text {leaf }}\right)}{R_{a}}$

$F_{\text {leaf }}=\frac{-\left(C_{\text {leaf }}\right)}{R_{b}+R_{C}}$

$F_{\text {trunk }}=\frac{-\left(C_{\text {leaf }}-C_{\text {trunk }}\right)}{R_{X}}$

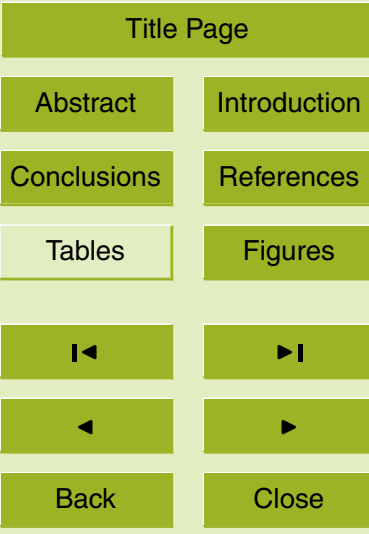

Full Screen / Esc

$C_{\text {leaf }}=\frac{C_{a i r} / R_{a}+C_{\text {trunk }} / R_{x}}{1 / R_{x}+1 / R_{a}+1 /\left(R_{b}+R_{C}\right)}$

Print Version

pean forests, possibly because of the much lower emission rates typically found in European ecosystems compared to those of the US (Simpson et al., 1999).

Interactive Discussion 
Now define $R_{q}=1 / R_{a}+1 / R_{x}+1 /\left(R_{b}+R_{c}\right)$ and the material going into the trunk space is:

$F_{\text {trunk }}=\frac{-\left(C_{\text {leaf }}-C_{\text {trunk }}\right)}{R_{x}}=-\left(\frac{C_{\text {air }} / R_{a}+C_{\text {trunk }} / R_{X}}{R_{x} R_{q}}-C_{\text {trunk }} / R_{x}\right)$

2, 1033-1065, 2005

The mass balance of material in the trunk space, for example for $\mathrm{NO}_{2}$, takes into ac5 count:

1. Material transported by turbulence from the atmosphere into the trunk-space minus the material transported from the trunk space to the atmosphere by turbulence.

2. Material produced (reaction between $\mathrm{O}_{3}$ and $\mathrm{NO}$ leading to $\mathrm{NO}_{2}$ ) and destructed (the photolysis of $\mathrm{NO}_{2}$ ) in the trunk-space.

3. Material taken up by plants in the under storey.

Or:

$\left(\frac{\mathrm{NO}_{2, \text { air }} / R_{a}+\mathrm{NO}_{2, \text { trunk }} / R_{x}}{R_{x} R_{q}}-\mathrm{NO}_{2, \text { trunk }} / R_{x}\right)$

$+k_{1} h_{\text {trunk }} \mathrm{O}_{3, \text { trunk }} \mathrm{NO}_{\text {trunk }}-j_{\mathrm{NO}_{2}, \text { trunk }} h_{\text {trunk }} \mathrm{NO}_{2, \text { trunk }}-\mathrm{NO}_{2, \text { trunk }} / R_{\mathrm{NO}_{2}, \text { lus }}=0$

15 with $h_{\text {trunk }}$ is the height of the trunk space parameterised here as $h_{\text {trunk }}=0.75 h_{\text {can }}$ and $R_{\mathrm{NO}_{2} \text {, lus }}$ the resistance to uptake by leaves of the plants in the under storey.

For $\mathrm{O}_{3}$ and $\mathrm{NO}$ the mass balance equations are similar and differ only by the sign of the chemical terms. An emission flux from the soil is added to the mass balance equation for NO.

\section{A simple model for air-forest exchange of $\mathrm{NO}_{\mathbf{x}}$ and $\mathrm{O}_{3}$}

J. Duyzer et al.

\section{Title Page}

Abstract Introduction

Conclusions

References

Tables

Figures

14

$\triangleleft$

Back

Close

Print Version

Interactive Discussion

EGU 
In the appendix it is shown how the three mass balance equations may be solved analytically and $C_{\text {trunk }}$ may be calculated from the resistances defined above, the emission of NO from soil, the light intensity above and below the canopy, and several characteristic parameters of the canopy such the Leaf Area Index (LAI), the canopy height 5 and the height of the trunk space.

Then the concentration at the leaf may be calculated for all three compounds $(i)$ from:

$C_{\text {leaf }, i}=\left(C_{\text {air }, i} / R_{a}+C_{\text {trunk }, i} / R_{x}\right) / R_{q, i}$

And the modelled flux from:

${ }_{10} F_{i, \bmod }=-\left(C_{a i r, i}-C_{\text {leat }, i}\right) / R_{a}$

Some notes on the model:

1. Values for the canopy resistances $R_{C, \mathrm{NO}_{2}}$ and $R_{C, \mathrm{O}_{3}}$ may, in principle, be derived from theory described for example by Baldocchi et al. (1987). The aim of this study however was to construct a model to use as a tool to explain $\mathrm{NO}_{2}$ fluxes observed above the canopy. Therefore in the first testing phase $R_{C, \mathrm{NO}_{2}}$ was estimated from $R_{C, \mathrm{O}_{3}}$ which allowed us to study $\mathrm{NO}_{2}$ fluxes unbiased by the scatter in estimates of $R_{C, \mathrm{NO}_{2}}$. By choosing this procedure a more focussed study of the processes affecting the flux of $\mathrm{NO}_{2}$ above the canopy can be carried out. The parameters needed to estimate the canopy resistances etc. were available for each forest and these will not be discussed here.

2. The most uncertain parameter in the model is the parameter describing the exchange between the leaf level and the trunk-space: $R_{X}$.

There is little information on this parameter. Rauner (1976) shows how in a deciduous forest the exchange coefficient $K_{z}$ (the ratio between fluxes and gradients i.e. defined in $F / u x_{x}=K_{z} \frac{d x}{d z}$ ) decreases linearly going down from the crown to the forest floor. At roughly half the height of the trees the exchange parameter is only

\section{A simple model for air-forest exchange of $\mathrm{NO}_{\mathbf{x}}$ and $\mathrm{O}_{3}$}

J. Duyzer et al.

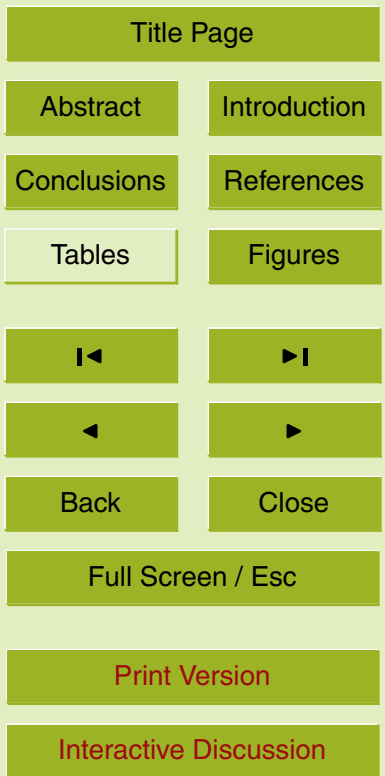

EGU 
half of the value at the top of the trees. Other authors (Thom, 1976) suggest that the $K_{z}$ value is still equal to $K_{z}=k u_{*} z$ its value above the canopy. With $u *$ the friction velocity and $k$ von Karman's constant. Note that in measurements carried out below the canopy at Speulderbos the friction velocity was only a few percent of its value above the canopy (Dorsey et al., 2004) the wind speed below the canopy is less than $5 \%$ of the wind speed at the observation level of $35 \mathrm{~m}$. Note that this value may be especially low in the Speulderbos site since this is a very dense forest with a $L A /$ of approximately $10 \mathrm{~m}^{2} / \mathrm{m}^{2}$.

Erisman et al. (1994), based upon van Pul and Jacobs (1994), provide a value of an "in-canopy" resistance equal to $R_{i n c}=b * L A l * h_{c a n} / u *$ This value was derived for maize with a very dense canopy and was not tested in other vegetation. Nevertheless the parameterisation of $R_{i n c}$ seems to make sense since it depends on parameters that would intuitively determine the resistance to transport in the canopy such as the height of the canopy $h_{c a n}$, the $L A l$ and the friction velocity. Therefore $R_{i n c}$ was chosen for this model here as the basis for parameterisation of $R_{x}$. In view of the lack of knowledge, a sensitivity study to the effect of varying this parameter was carried out. We thus use $R_{x}=R_{i n c} / \beta$ With $\beta$ ranging from 2 to 10.

This choice for $R_{i n c}$, as a basis for parameterisation of $R_{x}$ implies that the effect of the stability of the air in the forest is ignored. This seems a reasonable approach at this stage because stability effects inside the forest are difficult to describe. In contrast to the atmosphere above the canopy, the atmosphere in the forest will be stable during the day and unstable at night. In a small sensitivity study it was found that the results of the model calculations are not very sensitive to these stability effects.

3. The rate constant $k_{1}$ is calculated from air temperature according to: $k_{1}=2.9 / 60 *$ $\exp (-1400 / T)$ with $T$ the absolute temperature $j_{\mathrm{NO}_{2}}$ is calculated from observations of the global radiation below the canopy. In Speulderbos the photolysis rate

BGD

2, 1033-1065, 2005

\section{A simple model for air-forest exchange of $\mathrm{NO}_{x}$ and $\mathrm{O}_{3}$}

\section{J. Duyzer et al.}

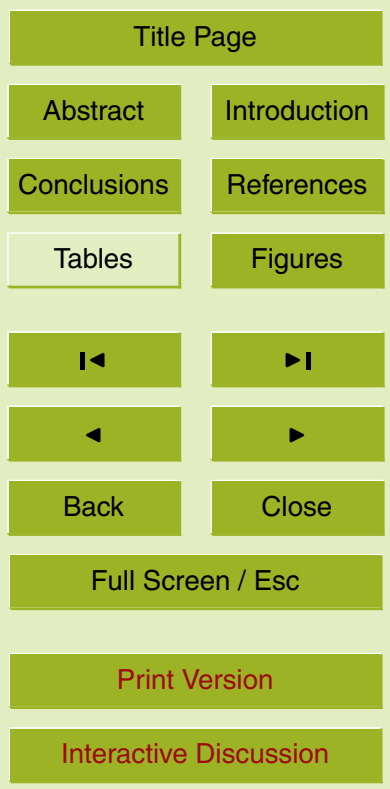

EGU 
was measured, incidentally, to be only $5 \%$ of the rate estimated from global radiation above the canopy. A sensitivity study with the model for Speuld showed that the model results are rather insensitive to the actual value.

4. The flux of NO from the soil was estimated from the parameterised results of more than two years of continuous measurements of the flux of NO at Speuld. During the intense campaign in 1993 only a few measurements could be carried out using a method described in van Dijk et al. (1998). The results of these measurements were used as a basis for parameterisation to estimate fluxes for Speuld. During the campaign in Soroe the emission of NO from the soil was measured continuously using dynamic enclosures. These measured values were used directly in the simulations.

\section{Description of the experimental sites and the experiments}

Two experiments where used to test the model. The experiment in Speulderbos was carried out in May-June 1993 and is described in detail in Dorsey et al. (2004).

The Speulderbos site $\left(52^{\circ} 15^{\prime} \mathrm{N} 5^{\circ} 41^{\prime} \mathrm{E}, 50 \mathrm{~m}\right.$ a.s.l.) consists of a homogeneous 2.5 ha monoculture of mature (planted in 1960) Douglas Fir. In the year of the experiment, 1993, the mean canopy height was $22.2 \mathrm{~m}$. Stem density varied between $765 \mathrm{ha}^{-1}$ in the east of the stand to $1216 \mathrm{ha}^{-1}$ in the west, with an average Diameter at Breast Height $(\mathrm{DBH})$ of $25.4 \mathrm{~cm}$. The 1993 annual average $L A /$ was approximately 10 , 20 and the leaf area density maximum lay between $10-14 \mathrm{~m}$. There was a high degree of canopy closure with virtually no tree foliage below $10 \mathrm{~m}$, - very little light was able to penetrate the canopy to the forest floor. There was, accordingly, little trunk-space vegetation. The site was surrounded by a larger forest of approximately $50 \mathrm{~km}^{2}$ and the fetch was characterized as mixed forest, with Pine, Beech, Oak, Douglas Fir and

During the experiments measurements of concentrations and fluxes were carried

\section{A simple model for air-forest exchange of $\mathrm{NO}_{\mathbf{x}}$ and $\mathrm{O}_{3}$}

J. Duyzer et al.

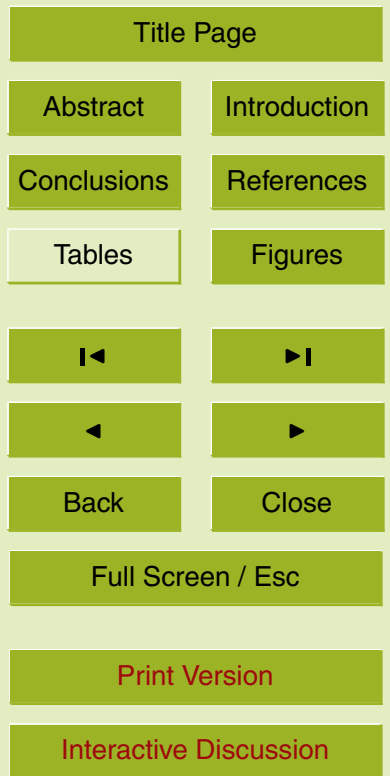

EGU 
out at several levels above and below the canopy top. At Speulderbos, for example, fluxes of ozone and nitrogen dioxide were measured at 35, 25 and $7 \mathrm{~m}$ height using dedicated monitors and sonic anemometers. Concentrations at these levels were also measured using slow response instrument that drew air from each level through a 5 specially designed gradient system. This had the advantage that each slow instrument could be used to calibrate all fast response sensors at each level in a continuous and consistent way. Systematic errors caused by drift in the fast response sensors could thus be avoided.

The experiment in Denmark was carried out in 2003. The Danish site is located 10 at $55^{\circ} 29^{\prime} \mathrm{N}, 11^{\circ} 38^{\prime} \mathrm{E}$ at an elevation of $40 \mathrm{~m}$ above mean sea level near Sorø on the island of Zealand. It is placed in an 80-year old beech (Fagus sylvatica L.) forest with an average tree height of $25 \mathrm{~m}$. The terrain is flat and there is a homogeneous fetch of $500-2000 \mathrm{~m}$. Average tree diameter is $40 \mathrm{~cm}$ and the stand density is 430 stem $\mathrm{ha}^{-1}$. The peak leaf area index of the canopy is about $4.75 \mathrm{~m}^{2} \mathrm{~m}^{-2}$ at the end of June 15 and the wood increment $11 \mathrm{~m}^{3} \mathrm{ha}^{-1}$ per year (1994). In April before bud-break there is flourishing forest floor vegetation mainly composed of Anemone nemorosa $L$. and Mercurialis perennis L.. Later in the summer, when penetrating light is scarce, the green vegetation on the forest floor mainly consists of patches of grasses. There are scattered stands of conifers (mainly Norway spruce Picea abies (L.) Karst.) as well as single trees of other conifers such as European larch (Larix decidua Mill.). In total, conifers constitute $20 \%$ of the footprint area. The soil is a mollisol with a $10-40 \mathrm{~cm}$ deep surface organic layer. The experimental set up was similar to that of Speulderbos.

\section{Results}

4.1. Measurements

25 In this chapter the performance of the model is illustrated by comparing results of model calculations with observations during the campaigns. In addition the sensitivity of the

\section{A simple model for air-forest exchange of $\mathrm{NO}_{\mathbf{x}}$ and $\mathrm{O}_{3}$}

J. Duyzer et al.

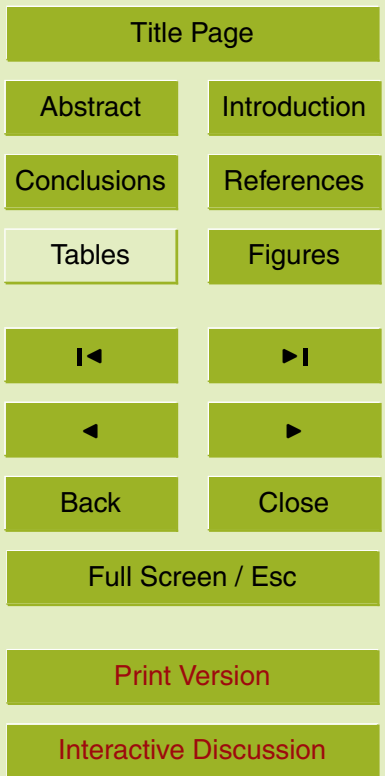

EGU 
model to the value of critical parameters is shown. It is important to realize at this stage that the quality of especially the measurements of the flux of $\mathrm{NO}_{2}$ is low compared to what would be required for true model testing. The concentrations of NO are very low and close to the detection limit which makes a comparison between the results of 5 measurements and model calculations less meaningful.

Figure 2 shows the results of measurements of $\mathrm{O}_{3}, \mathrm{NO}_{2}$ and the flux of $\mathrm{NO}$ from the soil at Speuld as an example. Hourly fluxes are derived from 10 min averages to reduce noise. Units are in ppb $\mathrm{m} / \mathrm{s}$ rather than $\mu \mathrm{g} / \mathrm{m}^{2} / \mathrm{s}$ to facilitate comparison. Note that the ozone flux is a factor of 5 to more than 10 larger than the $\mathrm{NO}_{2}$ flux and that the flux of $10 \mathrm{NO}$ from the soil is from a similar order of magnitude as the $\mathrm{NO}_{2}$ fluxes. Note also that the flux of $\mathrm{NO}_{2}$ is usually directed away from the forest surface and not towards the surface as could have expected from simple resistance layer calculations. It should be realised that the NO emission from the soil Speulderbos is high and among the highest observed in Europe (see Pilegaard et al., 2005). The observed effect could be much smaller at other sites with a smaller emission of NO from the soil.

It is obvious from Fig. 2 that the data suffer from a significant noise component. Much of the noise is removed by using hourly averages what is left is the random (low frequency) difference between the fluxes at 25 and $35 \mathrm{~m}$ level. For ozone these could amount to $25 \%$ (of the observed values) for individual hourly averages and for nitrogen dioxide up to $50 \%$. At this stage, we assume that these differences are caused by noise of all sorts i.e. instrumental noise as well as meteorological fluctuations. In principle the observed differences could have been caused by flux divergence between the two levels. Earlier studies have shown that only small flux divergence could be expected for ozone above this forest. An additional argument is that flux divergence would lead to conservation of the sum of the flux of $\mathrm{NO}_{2}$ plus $\mathrm{O}_{3}$. This is not what is observed.

It is important to realise the magnitude of the noise component in interpreting the comparison between observed fluxes and fluxes estimated using the model.

\section{A simple model for air-forest exchange of $\mathrm{NO}_{\mathbf{x}}$ and $\mathrm{O}_{3}$}

J. Duyzer et al.

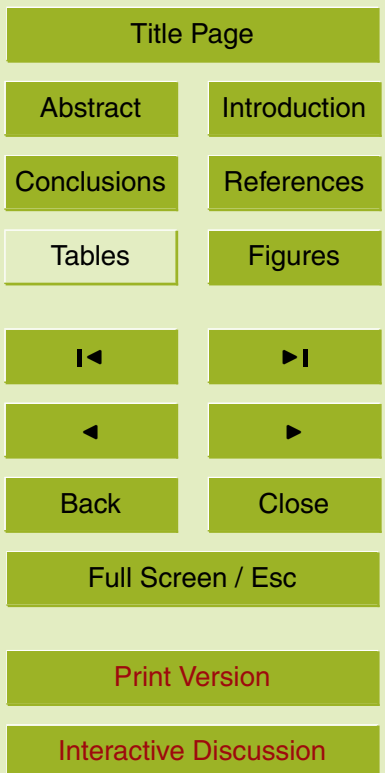

EGU 
As a first test model calculations were carried out and compared with a five day series of measurements carried out at Speulderbos in 1993.

The following parameters were input to the model:

- Concentration of $\mathrm{NO}, \mathrm{NO}_{2}, \mathrm{O}_{3}$ above the canopy.

- Information to calculate $R_{a}, R_{b}$ and $R_{c}$ such as

- Radiation, $T$, etc.

- Friction velocity

- Characteristics of the forest $\left(h_{\text {can }}, h_{\text {trunk }}, L A l\right)$

- Parameterisation of $R_{x}=R_{\text {inc }}$

- Fluxes of NO from the forest floor. In the model calculations these fluxes are derived from parameterised results of measurements in 2003 calibrated on measurements carried out during campaign.

This input will deliver the following output from the model:

- $\mathrm{NO}, \mathrm{NO}_{2}$ and $\mathrm{O}_{3}$ concentrations below canopy,

- NO, $\mathrm{NO}_{2}$ and $\mathrm{O}_{3}$ fluxes (above and below canopy).

\subsubsection{Concentrations below canopy}

The concentrations of $\mathrm{NO}_{2}$ and $\mathrm{O}_{3}$ were measured in the trunk space at $7 \mathrm{~m}$ height. These measurements provide good quality material for tests with the model. Data were used at 16 min time interval whereas the flux data were averaged to hourly averages to reduce noise.

Figures 3 and 4 show the concentration of $\mathrm{O}_{3}$ and $\mathrm{NO}_{2}$ concentration measured at $7 \mathrm{~m}$ and at $35 \mathrm{~m}$. The differences between these concentrations are, apart from a

A simple model for air-forest exchange of $\mathrm{NO}_{\mathbf{x}}$ and $\mathrm{O}_{3}$

J. Duyzer et al.

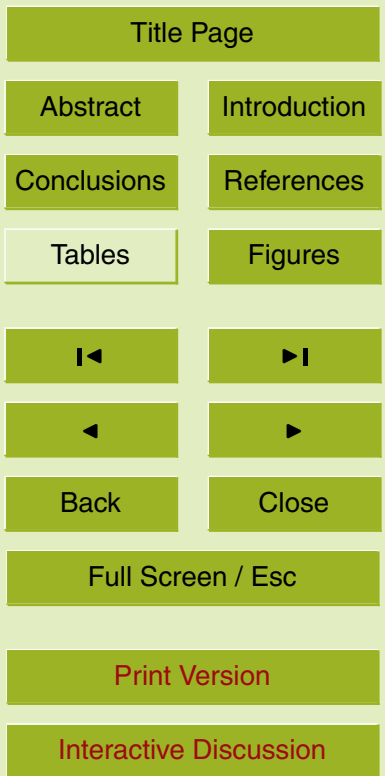

EGU 
few exceptions, smaller than $10 \%$ for ozone with the highest concentration above the canopy. For $\mathrm{NO}_{2}$ the differences are also small but now the lowest level shows usually higher concentrations in line with observations of an upward flux of $\mathrm{NO}_{2}$, i.e. away from the forest.

5 The base model is clearly underestimating the concentration of $\mathrm{O}_{3}$ at this level. This may be caused by too little exchange in the model, between the air in the trunk space and the atmosphere or by too much influence of the chemical reactions between NO (emitted from the soil) and $\mathrm{O}_{3}$ reducing the $\mathrm{O}_{3}$ concentration in the trunk area. At the same time the base model overestimates the $\mathrm{NO}_{2}$ concentration. This could have 10 exactly the same causes i.e. too little exchange with the atmosphere or a too high emission of $\mathrm{NO}$ leading to too high production of $\mathrm{NO}_{2}$.

In a small sensitivity study this effect was studied by reducing the value of $R_{X}$ to $R_{i n c} / 10$ and by switching off the emission of NO from the soil. The reduction of $R_{x}$ brings the $\mathrm{NO}_{2}$ concentrations to levels near the observed. If the emission of $\mathrm{NO}$ 15 is completely switched of in the model calculations, the calculated $\mathrm{NO}_{2}$ concentrations fall below the observed concentrations. A reasonable agreement is obtained with $R_{x}=R_{\text {inc }} / 10$.

If the exchange between the trunkspace and the atmosphere is increased by reducing $R_{x}$ by a factor of 10 the agreement between calculated and observed concentrations of $\mathrm{O}_{3}$ in the trunk space improves also considerably. In a simulation run carried out with no emission of $\mathrm{NO}$ at all the $\mathrm{O}_{3}$ concentration increases even slightly more. In some cases the calculated values are even higher than the observed values. The observations again confirm the results for $\mathrm{NO}_{2}$ that the best compromise is obtained when the value of $R_{x}$ is reduced by a factor of 10 . In other words: $R_{i n c}=1.4 * L a i * h_{\text {can }} / U *$.

25 4.2.2. $\mathrm{NO}_{2}$ flux

Figure 5 shows the results of calculations with the base model. A trivial but important result is that when chemical reactions are not included in the model there is no emission of $\mathrm{NO}_{2}$ observed. This is clearly in contrast with the observations. The base model

\section{BGD}

2, 1033-1065, 2005
A simple model for air-forest exchange of $\mathrm{NO}_{\mathbf{x}}$ and $\mathrm{O}_{3}$

J. Duyzer et al.

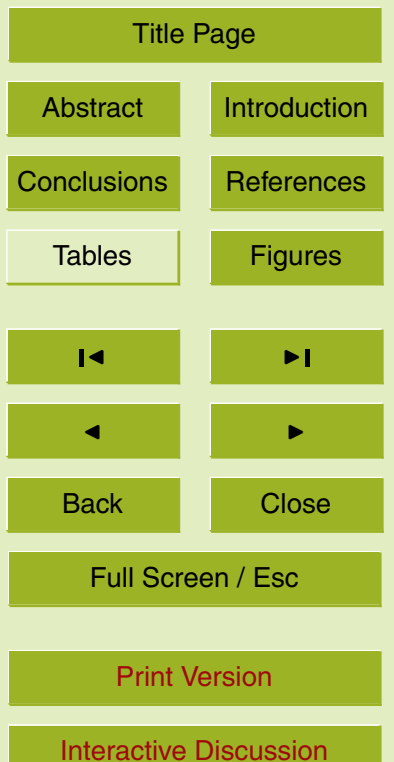

EGU 
improves upon this, indicating emissions of $\mathrm{NO}_{2}$ in some periods. Still large periods of deposition are calculated by the model contrary to the observations where emissions above the forest are observed most of the time.

Figure 6 shows some improvement as soon as the value of $R_{x}$ is decreased by a 5 factor of 10. This has the effect that the magnitude of emissions of $\mathrm{NO}_{2}$ is increased and the magnitude of the deposition fluxes is decreased. Now periods with deposition are nearly absent.

This figure also shows the influence of the emission of NO from the soil on the flux of $\mathrm{NO}_{2}$ observed above the canopy. Clearly when the $\mathrm{NO}$ emission increases 10 the emission of $\mathrm{NO}_{2}$ increases rapidly. When the $\mathrm{NO}$ emission rate from the soil is increased by a factor of four the emission of $\mathrm{NO}_{2}$ is much higher than observed. Note also that even if there is no $\mathrm{NO}$ emission from the soil, emission of $\mathrm{NO}_{2}$ above the forest is calculated by the model. This phenomenon is caused solely by conversion of $\mathrm{NO}$ and $\mathrm{O}_{3}$ (transported from above the canopy) and formation of $\mathrm{NO}_{2}$ in the trunk 15 space due to changed light conditions below the crown. This effect is at least as strong as the effect of NO emission.

\subsection{3. $\mathrm{O}_{3}$ fluxes}

Figure 7 shows the observed and calculated flux of $\mathrm{O}_{3}$ above the canopy. It should be realized that the values of $R_{C}$ chosen in the model calculations were derived from 20 the measurements of the ozone flux. This was done to focus on the effect of chemical reactions and not on the quality of the simulation of the ozone uptake. Clearly the influence of chemistry on the deposition is small during the daytime when the highest fluxes are observed. During the night the effect of chemistry could be as large as the flux itself. This was already observed earlier by Dorsey et al. (2004) They reported that 25 the downward flux of $\mathrm{O}_{3}$ observed at the $7 \mathrm{~m}$ was of the same order of magnitude as the flux observed above the canopy. According to the model calculations shown here these nocturnal fluxes could at least partly be caused by chemical reactions between

\section{A simple model for air-forest exchange of $\mathrm{NO}_{\mathbf{x}}$ and $\mathrm{O}_{3}$}

J. Duyzer et al.

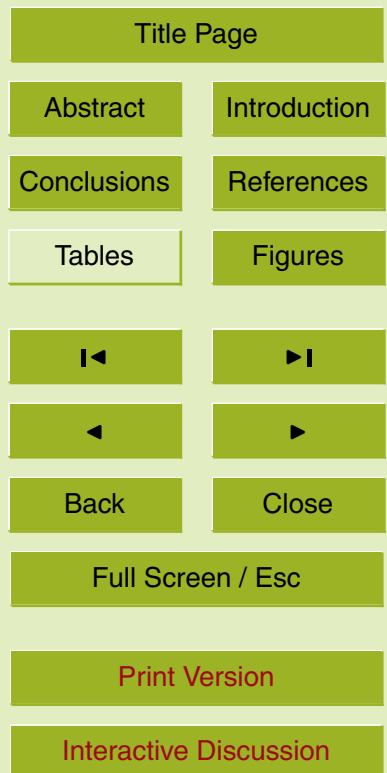

EGU 
Model calculations where also carried out for the experiment carried out in 2003 in Soroe. As was outlined above there are significant differences between the coniferous

5 Speulderbos and the beech forest in Soroe. In the context of this study important differences are:

1. the magnitude of the emission of NO from the soil,

2. the LAI,

3. the degree of light penetration to the trunk space.

10 Values for all relevant components were derived from observations during the experiment or from earlier studies. The base model shows reasonable agreement in some cases. At least upward fluxes are calculated during periods. In some cases the agreement improves when the exchange between the forest and the atmosphere is increased by lowering the value of $R_{x}$. In this case a decrease of a factor of 10 (as was needed to improve comparisons in Speuld) is by far too much. A factor of 2 provides some improvement.

\section{Discussion}

The comparison between the modelled and observed concentrations and fluxes of $\mathrm{NO}_{2}$ and $\mathrm{O}_{3}$ is not perfect. Considering the noise level in the observed fluxes this result is what could have been expected. Some interesting features in the observations can be understood using the model. There is some faith therefore that the model is capable of describing realistically the most important processes. It is therefore interesting to investigate the impact of chemistry on exchange of $\mathrm{O}_{3}$ and $\mathrm{NO}_{2}$ between the atmosphere and forest.

\section{A simple model for air-forest exchange of $\mathrm{NO}_{\mathbf{x}}$ and $\mathrm{O}_{3}$}

J. Duyzer et al.

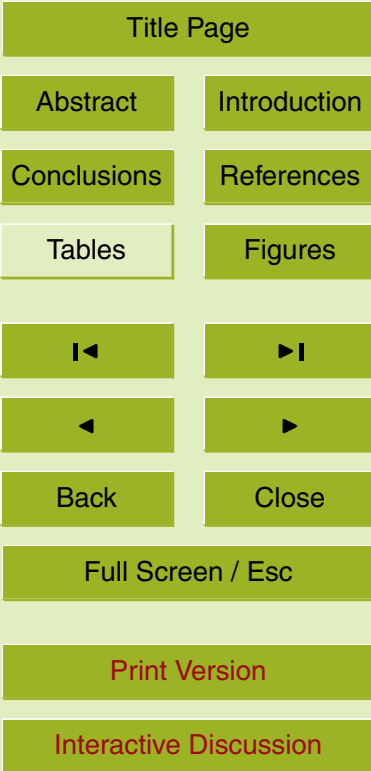

EGU 
Figure 9 shows fluxes of $\mathrm{NO}_{2}$ and $\mathrm{NO}$ to Speulderbos calculated using the "2layer" model. If deposition is interesting from the effect point of view (be it eutrofication or acidification) the net input into the forest of $\mathrm{N}$ (the sum of the fluxes of $\mathrm{NO}$ and $\mathrm{NO}_{2}$ ) is important. Figure 9 shows that the flux of $\mathrm{NO}$ above the canopy is usually rather 5 small and going from small upward fluxes to small downward fluxes. The flux of $\mathrm{NO}_{2}$ above the canopy is larger but both upwards as well as downwards. It is obvious from Figure 9 that measurement of the $\mathrm{NO}_{2}$ flux is in this case the able method to estimate the nitrogen flux to the forest if flux of $\mathrm{NO}$ is not measured. The flux calculated from the deposition velocity $\left(v_{d}\right)$ and the $\mathrm{NO}_{2}$ concentration as is the classical procedure in 10 large scale model calculations does not provide the true flux. In some cases correction for the emission of NO from the soil leads to some improvement. When all NO is converted in the trunk space the net ecosystem flux maybe estimated. But when $\mathrm{O}_{3}$ levels are too low this may not be the case and $\mathrm{NO}$ is vented into the atmosphere. It should be realized that even if NO emission is very small there is still an effect because of difference in light conditions between the trunk space and the atmosphere during the day.

At this stage the best solution to obtain an estimate of the net $\mathrm{N}$ flux into the canopy would be use the model described here since it takes all relevant processes into account

20 Whereas the influence of canopy processes on the deposition of $\mathrm{NO}_{2}$ is rather obvious it is interesting to see the effect on the deposition rate of $\mathrm{O}_{3}$. Figures 10 and 11 show the impact of canopy chemistry on the estimation of the deposition velocity of ozone. As was pointed out above the impact on the high deposition flux in the daytime is probably low. At night however the impact may be large especially when the emission of NO is as large as it is in Speulderbos. Figure 10 shows how this effect could be as large as $100 \%$ at night. But even in Soroe the impact could be significant at night as is illustrated in Fig. 11.

\section{BGD}

2, 1033-1065, 2005

\section{A simple model for air-forest exchange of $\mathrm{NO}_{\mathbf{x}}$ and $\mathrm{O}_{3}$}

J. Duyzer et al.

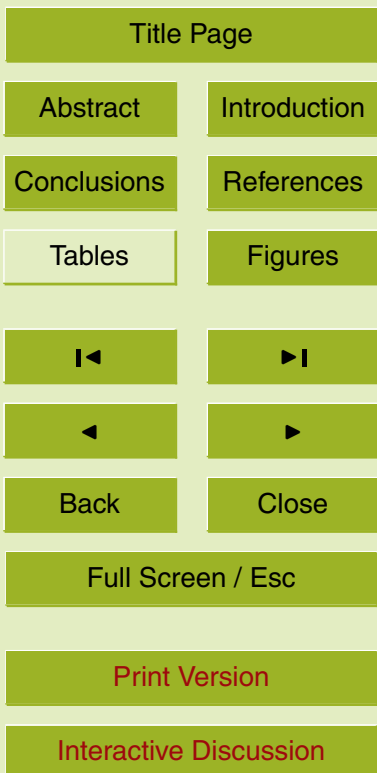

EGU 


\section{Concluding remarks}

The model calculations presented in this paper illustrate the complexity of exchange between the atmosphere an forests especially for reactive trace gases. The model developed is so simple that it may be implemented in the EMEP model. It should be

5 realised that the approach taken is not taking into account modern theories considering turbulent exchange between forests and the atmosphere. It should also be realised that even the most complex models have trouble capturing major features of forest turbulence, and are in any case not applicable on any practical scale (Raupach and Finnigan, 1988). On the other hand the paper shows how poor the quality of the observations of fluxes of reactive nitrogen gases is compared to the modellers needs. The model is therefore useful only to show the major features. Two important effects could be shown in this study: The deposition of ozone by forests seems to be influenced significantly by chemical reactions in the trunk space especially during the night and in forests with high emission rates of NO. It is also obvious that the estimation of the oxidised nitrogen flux from the $\mathrm{NO}_{2}$ concentration and the deposition velocity could deviate significantly from the true flux.

\section{Appendix A}

The mass balance for the trunk space for $\mathrm{NO}_{2}$ equals to

$$
\left(\frac{\mathrm{NO}_{2, \text { air }} / R_{a}+\mathrm{NO}_{2, \text { trunk }} / R_{X}}{R_{X} R_{q}}-\mathrm{NO}_{2, \text { trunk }} / R_{X}\right)+k h_{\text {trunk }} \mathrm{O}_{3, \text { trunk }} \mathrm{NO}_{\text {trunk }}
$$

$20-j_{\mathrm{NO}_{2}, \text { trunk }} h_{\text {trunk }} \mathrm{NO}_{2, \text { trunk }}-\mathrm{NO}_{2, \text { trunk }} / R_{\mathrm{NO}_{2}, \text { us }}=0$

where $j_{\mathrm{NO}_{2}}=$ the photolysis rate of $\mathrm{NO}_{2}$ in the trunk space estimated to be $1.5 \%$ (Speuld) or $15 \%$ (Soroe) of the photolysis rate above the canopy (calculated from global
BGD

2, 1033-1065, 2005

A simple model for air-forest exchange of $\mathrm{NO}_{\mathbf{x}}$ and $\mathrm{O}_{3}$

J. Duyzer et al.

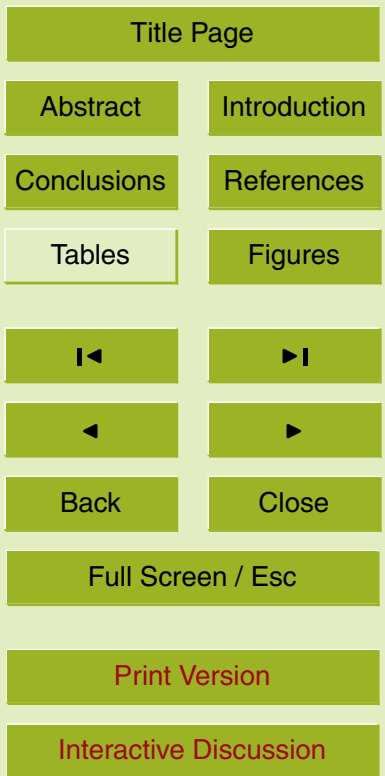

EGU 
radiation) and $k$ the rate constants of the reaction between $\mathrm{NO}$ and $\mathrm{O}_{3} . h_{\text {trunk }}$ is the height of the trunk space parameterised here as $h_{\text {trunk }}=0.75 h_{\text {can }}$.

The three mass balance equations may be solved algebraically to calculate the concentrations in the trunk-space.

$\mathrm{NO}_{2, \text { trunk }}=f_{1} *\left(a_{\mathrm{NO}_{2}}+k_{*} h_{\text {trunk }}+f_{2} *\left(b_{\mathrm{O}_{3}}+2 * b_{\mathrm{NO}_{2}}+b_{\mathrm{NO}}\right)-D e t\right)$

$5 \quad \mathrm{O}_{3, \text { trunk }}=1 / a_{\mathrm{O}_{3}} *\left(b_{\mathrm{O}_{3}}+b_{\mathrm{NO}_{2}}-a_{\mathrm{NO}_{2}} * \mathrm{NO}_{2, \text { trunk }}\right)$

$\mathrm{NO}_{\text {trunk }}=1 / a_{\mathrm{NO}} *\left(b_{\mathrm{NO}_{2}}+b_{\mathrm{NO}}-a_{\mathrm{NO}_{2}} * \mathrm{NO}_{2, \text { trunk }}\right)$

Det $=\left(\left(a_{\mathrm{NO}_{2}+} j_{\mathrm{NO}_{2}} * h_{\text {trunk }}\right)+f_{2} *\left(b_{\mathrm{O}_{3}}+2 * b_{\mathrm{NO}_{2}}+b_{\mathrm{NO}}\right)\right) \wedge 2-4 * f_{3} *$

$\left.\left.\left(b_{\mathrm{NO}_{2}}+k * h_{\text {trunk }} / a_{\mathrm{O}_{3}} / a_{\mathrm{NO}} *\left(b_{\mathrm{O}_{3}}+b_{\mathrm{NO}_{2}}\right) *\left(b_{\mathrm{NO}_{2}}+b n o\right)\right)\right) \wedge .5\right)$

$R_{q_{i}}=\left(1 / R_{a}+1 / R_{x}+1 /\left(R_{b, i}+R_{c, i}\right)\right.$

$b_{i}=1 / R_{a} / R_{x} / R_{q_{i}} * C_{a i r, i}+F_{i, \text { soil }}$

$a_{i}=1 / R_{x}-1 / R_{x} / R_{x} / R_{q_{i}}+1 /\left(R_{\text {soil }, i}+R_{\text {lus }, i}+f_{\text {bottom }} * R_{\text {inc }}\right)$

With $R_{b, i}$ representing the classical boundary layer resistance and $R_{c, i}$ the canopy resistance, $R_{\text {soil }, i}$ the resistance to uptake by soil, $R_{\text {lus }, i}$ the resistance to uptake by the under storey $C_{a i r, i}$ representing the concentration in the air above the canopy, and $F_{i, \text { soil }}$ is the soil emission flux (only non-zero for $\mathrm{NO}$ ) for $i=\mathrm{NO}, \mathrm{NO}_{2}$ or $\mathrm{O}_{3}$, respectively.

$R_{i n c}$ is the resistance derived from measurements in maize by van Pul et al. (1994) and calculated from:

$R_{\text {inc }}=14 * L A l * h_{\text {can }} / U *$

With $L A l$ the leaf area index $h_{c a n}$ the canopy height and $u *$ the friction velocity. The factor 14 is rather uncertain.

Several authors have indicated the resistance to exchange increases going down from the crown area to the forest floor. This difference is accounted for by introducing 1050
Abstract

Conclusions

\section{A simple model for air-forest exchange of $\mathrm{NO}_{\mathbf{x}}$ and $\mathrm{O}_{3}$}

J. Duyzer et al.

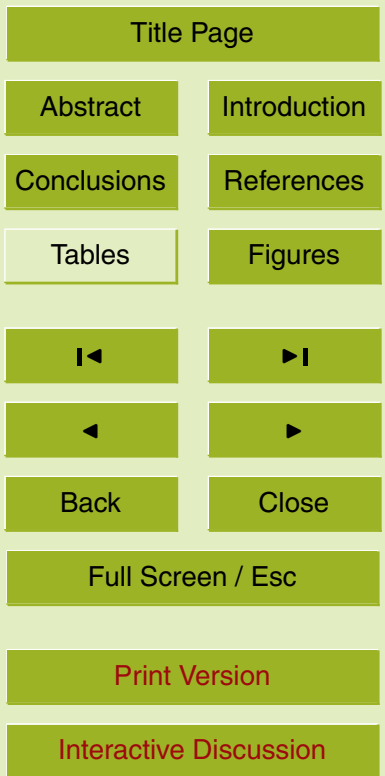

EGU 
the factors $f_{\text {bottom }}$ and $f_{\text {top }}$. The values where derived from calculations with our multilayer canopy model described in Duyzer et al. (2004) i.e. $f_{\text {top }}=0.1$ and $f_{\text {bottom }}=0.9$ and therefore: $R_{x}=f_{\text {top }} * R_{\text {inc }}$.

Note that by choosing this parameterisation the uptake op $\mathrm{O}_{3}$ and $\mathrm{NO}_{2}$ by the under 5 storey and the soil is still represented exactly similar to the classical resistance layer model using $R_{i n c}$ i.e. the model gives exactly what the classical resistance layer model would give. Further:

$f_{1}=a_{\mathrm{O}_{3}} * a_{\mathrm{NO}} / 2 / k_{1} / h_{\text {trunk }} / a_{\mathrm{NO}_{2}} / a_{\mathrm{NO}_{2}}$

$f_{2}=a_{\mathrm{NO}_{2}} * k_{1} * h_{\text {trunk }} / a_{\mathrm{O}_{3}} / a_{\mathrm{NO}}$

$10 f_{3}=k_{1} * h_{\text {trunk }} * a_{\mathrm{NO}_{2}} * a_{\mathrm{NO}_{2}} / a_{\mathrm{O}_{3}} / a_{\mathrm{NO}}$

And finally:

$C_{\text {leaf }, i}=\left(C_{\text {air }, i} / R_{a}+C_{\text {trunk }, i} / R_{x}\right) / R_{q, i}$

$F_{i, \bmod }=-1 *\left(C_{a i r, i}-C_{l e a f, i}\right) / R_{a}$

A simple model for air-forest exchange of $\mathrm{NO}_{\mathbf{x}}$ and $\mathrm{O}_{3}$

J. Duyzer et al.

Due to the change in light conditions the equilibrium that existed above the canopy will 15 be altered.

Note that uptake of $\mathrm{NO}$ at the surface of the leaves is assumed to be unimportant.

Acknowledgements. The work described here was carried out in the framework of the project NOFRETETE which was funded by the European Community under CT2001-00106. The measurements used for comparison with model results were obtained in the framework of an older EC funded project FOREXNOX under EV5V-CT92-0060.

\section{References}

Baldocchi, D. D., Hicks, B. B., and Camara, P.: A canopy stomatal resistance model for gaseous deposition to vegetated surfaces, Atmosp. Env., 21, 91-101, 1987.

\section{Title Page}

Abstract

Introduction

Conclusions

References

Tables

Figures

14

4

Back

Close

Full Screen / Esc

Print Version

Interactive Discussion 
Coe, $\mathrm{H}$. and Gallagher, M. W.: Measurements of dry deposition of $\mathrm{NO}_{2}$ to Dutch heath land using the eddy correlation technique, Quarterly Journal of the Royal Meteorological Society, 118, 767-786, 1992.

Dorsey, J. H., Duyzer, J. H., Gallagher, M. W., Coe, H., Pilegaard, K., Weststrate, J. H., Jensen, $5 \quad$ N. O., and Walton, S.: Oxidized nitrogen and ozone interaction with forests, I: Experimental observations and analysis of exchange with Douglas fir, Quarterly Journal of the Royal Meteorological Society, 130 Part A, 600, 1941-1955, 2004.

Duyzer, J. H., Dorsey, J. R., Gallagher, M. W., Pilegaard, K., and Walton, S.: Oxidized nitrogen and ozone interaction with forests, II: Multi-layer process-oriented modelling results and a sensitivity study for Douglas fir, Quarterly Journal of the Royal Meteorological Society, 130 Part A, 600, 1957-1972, 2004.

Duyzer J. H., Meijer, G. M., and van Aalst, R. M.: Measurement of dry deposition velocities of $\mathrm{NO}, \mathrm{NO}_{2}$ and $\mathrm{O}_{3}$ and the influence of chemical reactions, Atmos. Env., 17, 10 2117-2120, 1983.

Duyzer, J., Walton, S., Gallagher, M., and Pilegaard, K.: A multi-layer model to describe the exchange of $\mathrm{NO}_{x}$ and $\mathrm{O}_{3}$ above and below forest canopies, IMW TNO report R95/113, Delft, the Netherlands, 1995.

Duyzer, J. H., Deinum, G., and Baak, J.: The interpretation of measurements of surface exchange of nitrogen oxides; corrections for chemical reactions, Philosophical Transactions of 20 the Royal Society of London A, 351, 1-18, 1995.

Duyzer, J. H., Weststrate, J. H., and Walton, S.: Exchange of ozone and nitrogen oxides between the atmosphere and forest, Journal of Water, Air and Soil Pollution, 85, 2065-2070, 1996.

Erisman, J. W., Van Pul, A., and Wyers, P.: Parameterization of dry deposition mechanisms for the quantification of atmospheric deposition of acidifying pollutants and ozone, Atmos. Env., 16, 2595-2607, 1994.

Fitzjarrald. D. R. and Lenschow, D. H.: Mean Concentration and flux profiles for chemically reactive species in the atmospheric surface layer, Atmos. Env., 17, 12, 2505-2512, 1983.

Gao, W., Wesely, M. L., Lee, I. Y.: A numerical study of the effects of air chemistry on fluxes of $\mathrm{NO}, \mathrm{NO}_{2}$ and $\mathrm{O}_{3}$ near the surface, J. Geophys. Res., 96, D10, 18 761-18769, 1991.

Galmarini, S., De Arellano, J. v. G., and Duyzer, J.: Fluxes of chemically reactive species inferred from mean concentration measurements, Atmos. Env., 31, 15, 2371-2374, 1997.

Goldstein, A., McKay, M., Schade, G., Lee, A., Holzinger, R., and Rasmussen, R.: Forest

\section{A simple model for air-forest exchange of $\mathrm{NO}_{\mathbf{x}}$ and $\mathrm{O}_{3}$}

J. Duyzer et al.

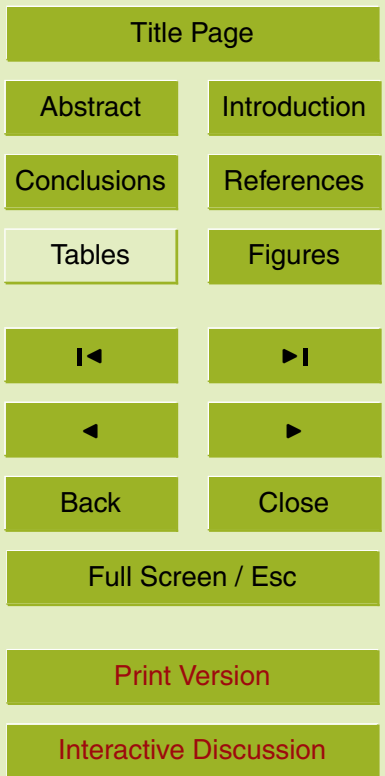

EGU 
thinning experiment confirms ozone deposition to a forest canopy is dominated by reaction with biogenic VOCs, Geophys. Res. Lett., 31, L22 106, doi:1029/2004GL021259, 2004.

Hicks, B. B., Matt, D. R., McMillen, R. J., Womack, J. D., and Shetter, R. E.: Eddy fluxes of nitrogen oxides to a deciduous forest in complex terrain, in: The meteorology of acid deposition, APCA, 189-201, 1983.

Hicks, B. B., Matt, D. R., and Mcmillen, R. T.: A micrometeorological investigation of surface exchange of $\mathrm{O}_{3}, \mathrm{SO}_{2}$ and NO: a case study, Boundary Layer Meteorology, 47, 321-336, 1989.

Hicks, B. B., Wesely, M. L., Coulter, R. L., Hart, R. L., Durham, J. L., Speer, R., and Stedman, D. $\mathrm{H}$.: An experimental study of sulphur and $\mathrm{NO}_{\mathrm{x}}$ fluxes over grassland, Boundary Layer Meteorology, 34, 103-121, 1986.

Kramm, G., Müller, H., Fowler, D., Höfken, K. D., Meixner, F. X., and Schaller, E.: A modified profile method for determining the vertical fluxes of $\mathrm{NO}, \mathrm{NO}_{2}, \mathrm{O}_{3}$ and $\mathrm{HNO}_{3}$ in the atmospheric surface layer, J. Atmos. Chem., 13, 265-288, 1991.

15 Pilegaard, K. Hummelshøjb, N., Jensen, O., and Chenc, Z.: Two years of continuous $\mathrm{CO}_{2}$ eddy-flux measurements over a Danish beech forest, Agricultural and Forest Meteorology, 107, 29-41, 2001.

Simpson, D., Winiwarter, W., Börjesson, G., Cinderby, S., Ferreiro, A., Guenther, A., Hewitt, C. N., Janson, R., Khalil, M. A. K., Owen, S., Pierce, T. E., Puxbaum, H., Shearer, M., Skiba, U., Steinbrecher, R., Tarrasón, L., and Öquist, M. G: Inventorying emissions from Nature in Europe, J. Geophys. Res., 104, 8113-8152, 1999.

Rauner, Ju. L.: Deciduous forests, in: Vegetation and the Atmosphere, edited by: Monteith, J. L., Academic Press London, 2, 171-240, 1976.

Raupach, M. R. and Finnigan, J. J.: Single layer models of evapotranspiration from plant communities are incorrect, but useful, whereas multi-layer models are correct but useless: discussion, Australian Journal of Plant Physiology, 15, 705-716, 1988.

Simpson, D., Tuovinen, J.-P., Emberson, L., and Ashmore, M.: Characteristics of an ozone deposition module, Water, Air and Soil Pollution, Focus, 1, 253-262, 2001.

Simpson, D., Fagerli, H., Jonson, J., Tsyro, S., Wind, P., and Tuovinen, J.-P.: The EMEP Unified Eulerian Model, Model Description, EMEP MSC-W Report 1/2003, The Norwegian Meteorological Institute, Oslo, Norway, 2003.

Thom, A. S.: Momentum, mass and heat exchange, in: Vegetation and the Atmosphere, edited by: Monteith, J. L., Academic Press London, 1, 57-109, 1976.
BGD

2, 1033-1065, 2005

A simple model for air-forest exchange of $\mathrm{NO}_{x}$ and $\mathrm{O}_{3}$

J. Duyzer et al.

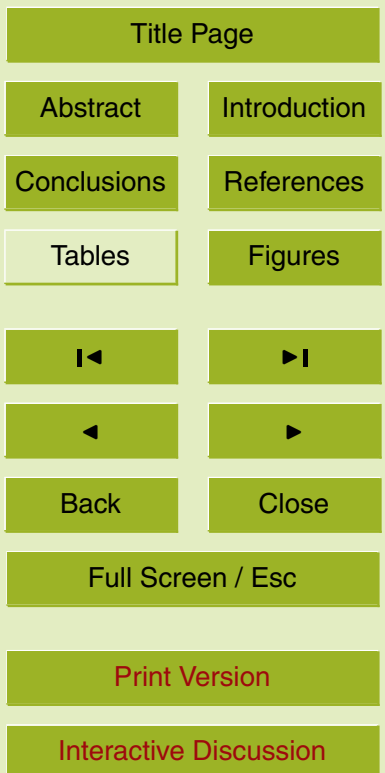

EGU 
Tuovinen, J.-P., Simpson, D., Mikkelsen, T., Emberson, L., M., M. R. A., Aurela, Cambridge, H. M., Hovmand, M. F., Jensen, N. O., Laurila, T., Pilegaard, K., and Ro-Poulsen, H.: Comparisons of measured and modelled ozone deposition to forests in Northern Europe, Water, Air and Soil Pollution, Focus, 1, 263-274, 2001.

Pul, W. A. J. van and Jacobs, A. F. G.: The conductance of a maize crop and the underlying soil to ozone under various environmental conditions, Boundary Layer Meteorology, 69, 83-99, 1994.

Walton, S., Gallagher, M. W., Choularton, T. W., and Duyzer, J.: Ozone and $\mathrm{NO}_{2}$ exchange to fruit orchards, Atmos. Env., 31, 17, 2767-2776, 1997a.

10 Walton, S., Gallagher, M. W., and Duyzer, J. H.: Use of a detailed model to study the exchange of $\mathrm{NO}_{\mathrm{x}}$ and $\mathrm{O}_{3}$ above and below a deciduous canopy, Atmos. Env., 31, 18, 2915-2932, 1997b.

Wesely, M. L., Eastman, J. A., Stedman, D. H., and Yolvac, E. D.: An eddy correlation measurement of $\mathrm{NO}_{2}$ flux to vegetation and comparison to $\mathrm{O}_{3}$ flux, Atmos. Env., 16, 4, 815-820, 1982.

2, 1033-1065, 2005

A simple model for air-forest exchange of $\mathrm{NO}_{\mathbf{x}}$ and $\mathrm{O}_{3}$

J. Duyzer et al.

\section{Title Page}

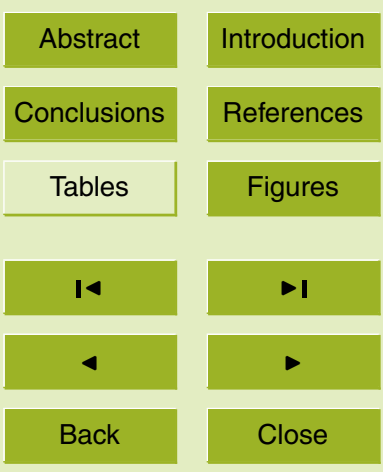

Full Screen / Esc

Print Version

Interactive Discussion 
BGD

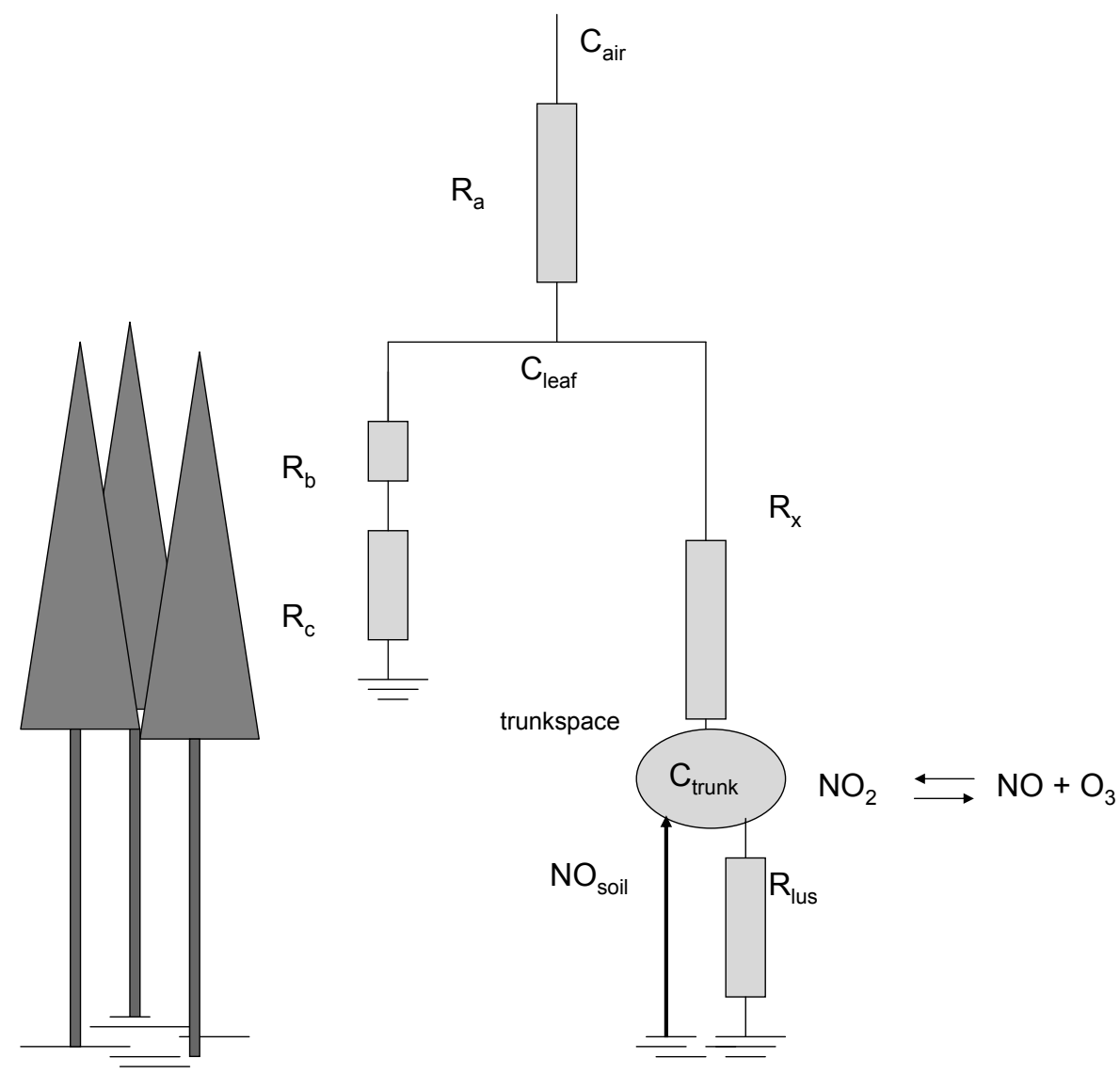

2, 1033-1065, 2005

A simple model for air-forest exchange of $\mathrm{NO}_{x}$ and $\mathrm{O}_{3}$

J. Duyzer et al.

\section{Title Page}

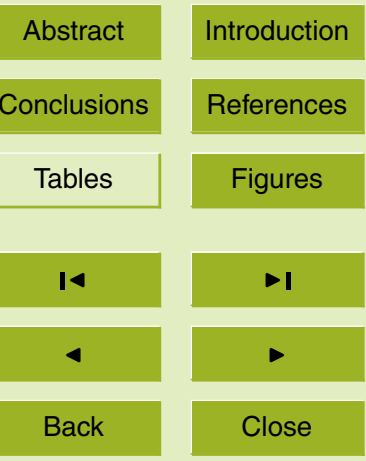

Full Screen / Esc

Print Version

Interactive Discussion

Fig. 1. Schematic of the resistance layer model described in the text. 
BGD

2, 1033-1065, 2005

\section{A simple model for air-forest exchange of $\mathrm{NO}_{\mathrm{x}}$ and $\mathrm{O}_{3}$}

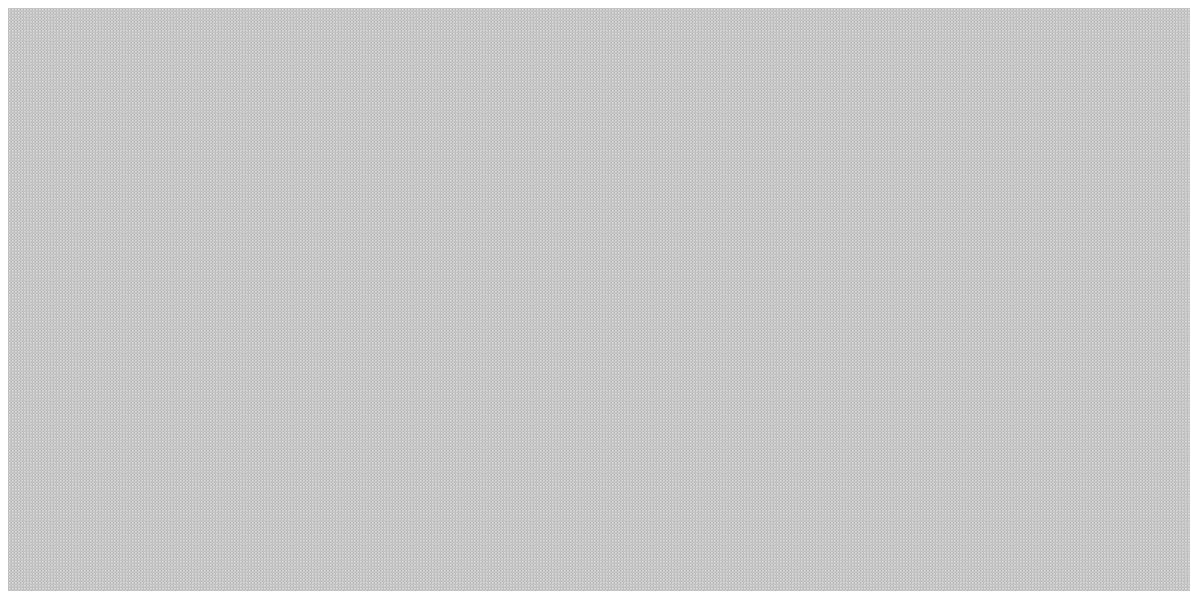

J. Duyzer et al.

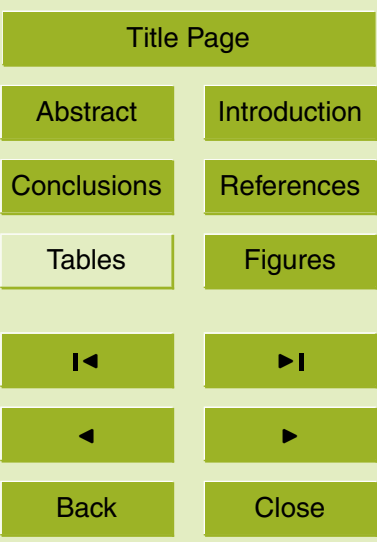

Fig. 2. Fluxes of $\mathrm{O}_{3}, \mathrm{NO}_{2}$ observe above the canopy in Speulderbos and the emission of $\mathrm{NO}$ from the soil calculated from parameterised results.

Full Screen / Esc

Print Version

Interactive Discussion

EGU 
BGD

2, 1033-1065, 2005

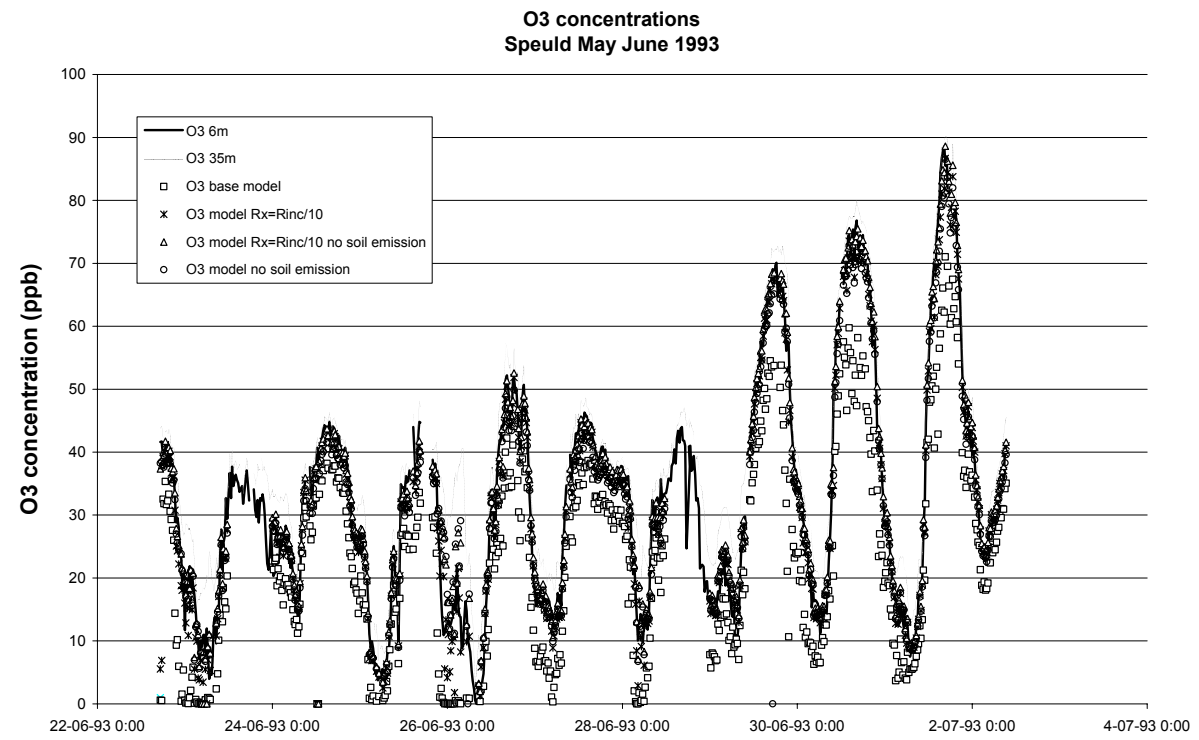

A simple model for air-forest exchange of $\mathrm{NO}_{\mathrm{x}}$ and $\mathrm{O}_{3}$

J. Duyzer et al.

\section{Title Page}

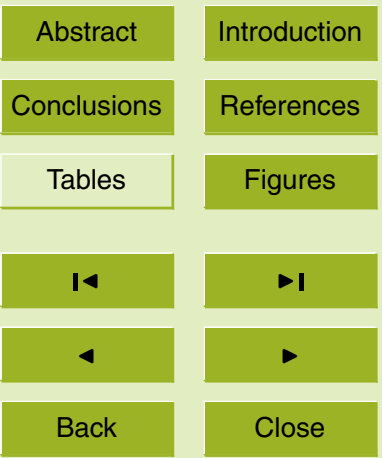

Fig. 3. The concentration of $\mathrm{NO}_{2}$ at $7 \mathrm{~m}$ observed during the experiment in Speulderbos compared with concentrations calculated with the model for different values of $R_{X}$ and the emission

\section{Full Screen / Esc} of NO from the soil.

Print Version

Interactive Discussion

EGU 
BGD

2, 1033-1065, 2005

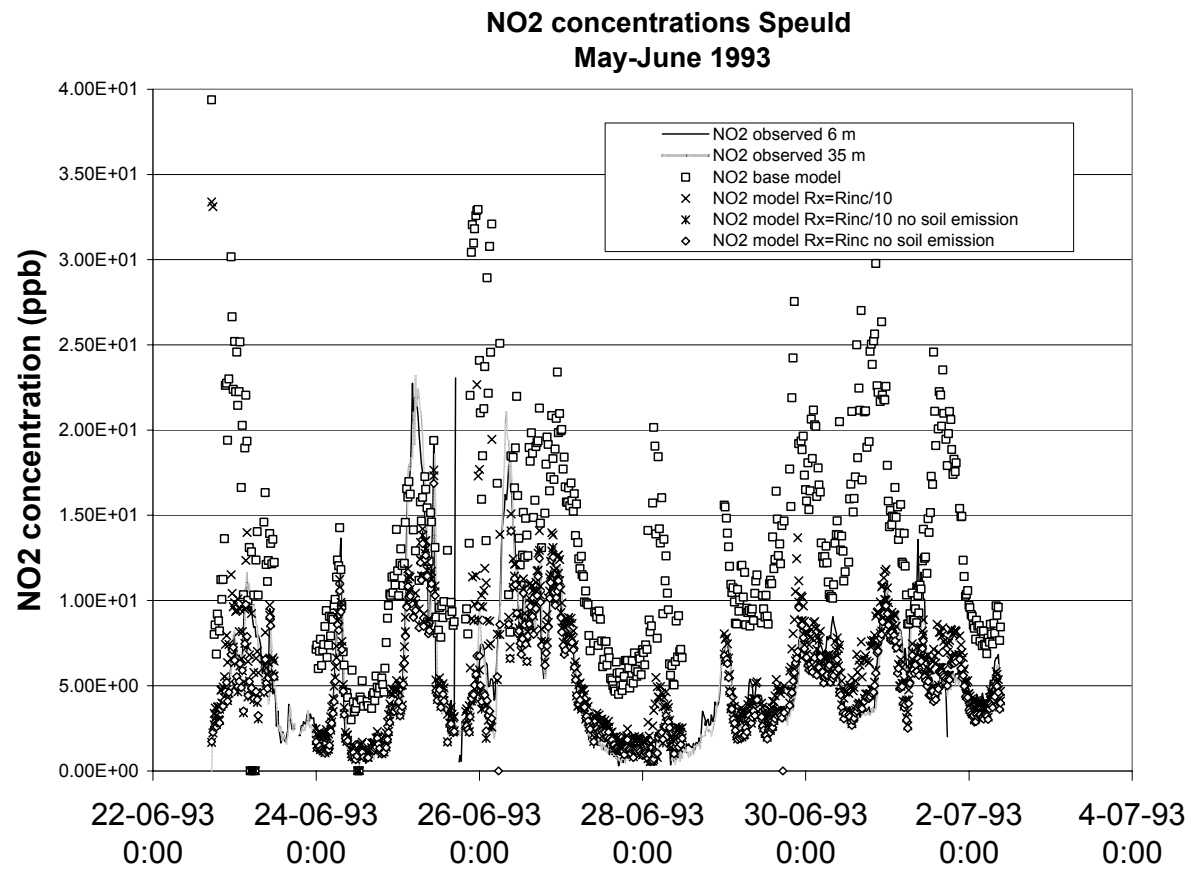

A simple model for air-forest exchange of $\mathrm{NO}_{\mathrm{x}}$ and $\mathrm{O}_{3}$

J. Duyzer et al.

\section{Title Page}

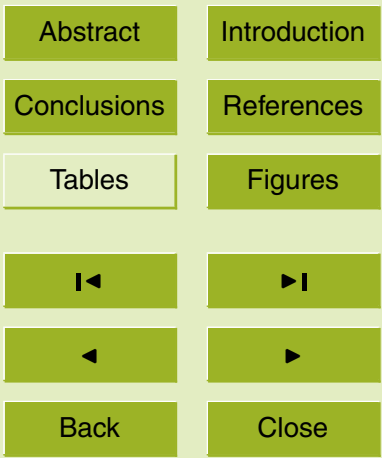

Full Screen / Esc

Fig. 4. The concentration of $\mathrm{O}_{3}$ at $7 \mathrm{~m}$ observed during the experiment in Speulderbos compared with concentrations calculated with the model for different values of $R_{X}$ and the emission of NO from the soil.

Print Version

Interactive Discussion 
BGD

2, 1033-1065, 2005

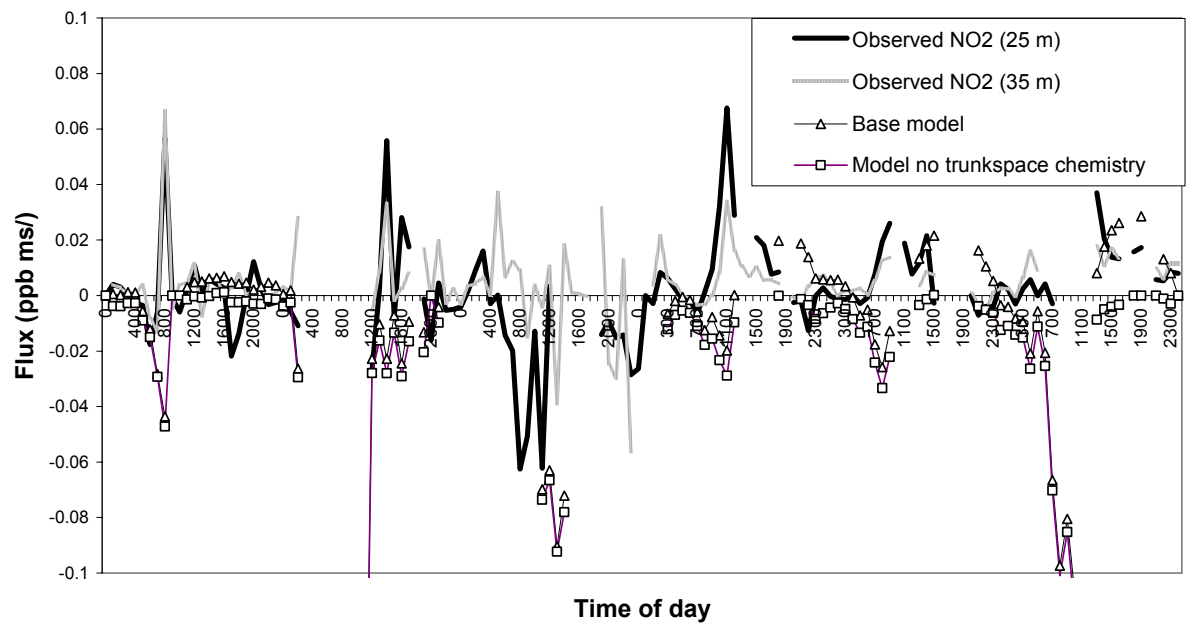

A simple model for air-forest exchange of $\mathrm{NO}_{\mathrm{x}}$ and $\mathrm{O}_{3}$

J. Duyzer et al.

\section{Title Page}

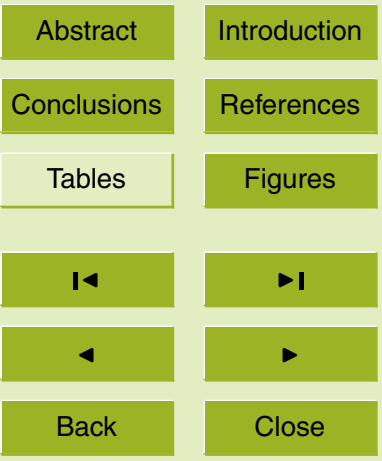

Fig. 5. The flux of $\mathrm{NO}_{2}$ above Speulderbos and the flux calculated with the 2layer model using different parameters when running the model.

Full Screen / Esc

Print Version

Interactive Discussion

EGU 
BGD

2, 1033-1065, 2005

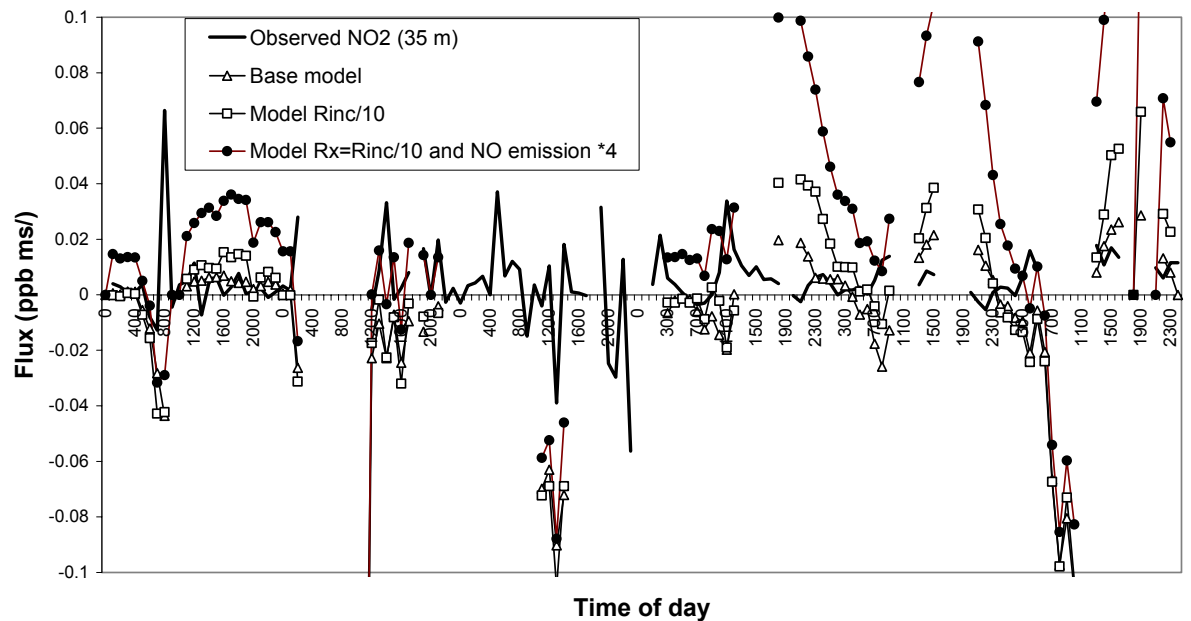

A simple model for air-forest exchange of $\mathrm{NO}_{\mathrm{x}}$ and $\mathrm{O}_{3}$

J. Duyzer et al.

\section{Title Page}

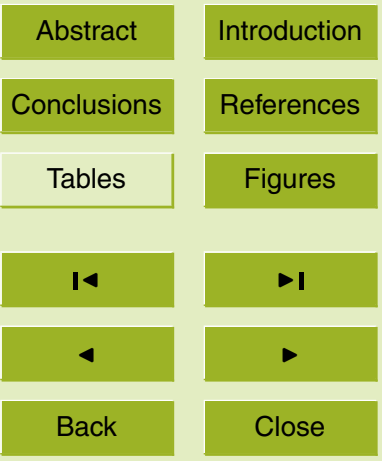

Fig. 6. The flux of $\mathrm{NO}_{2}$ above Speulderbos and the flux calculated with the 2layer model using different parameters when running the model.

Full Screen / Esc

Print Version

Interactive Discussion

EGU 
BGD

2, 1033-1065, 2005

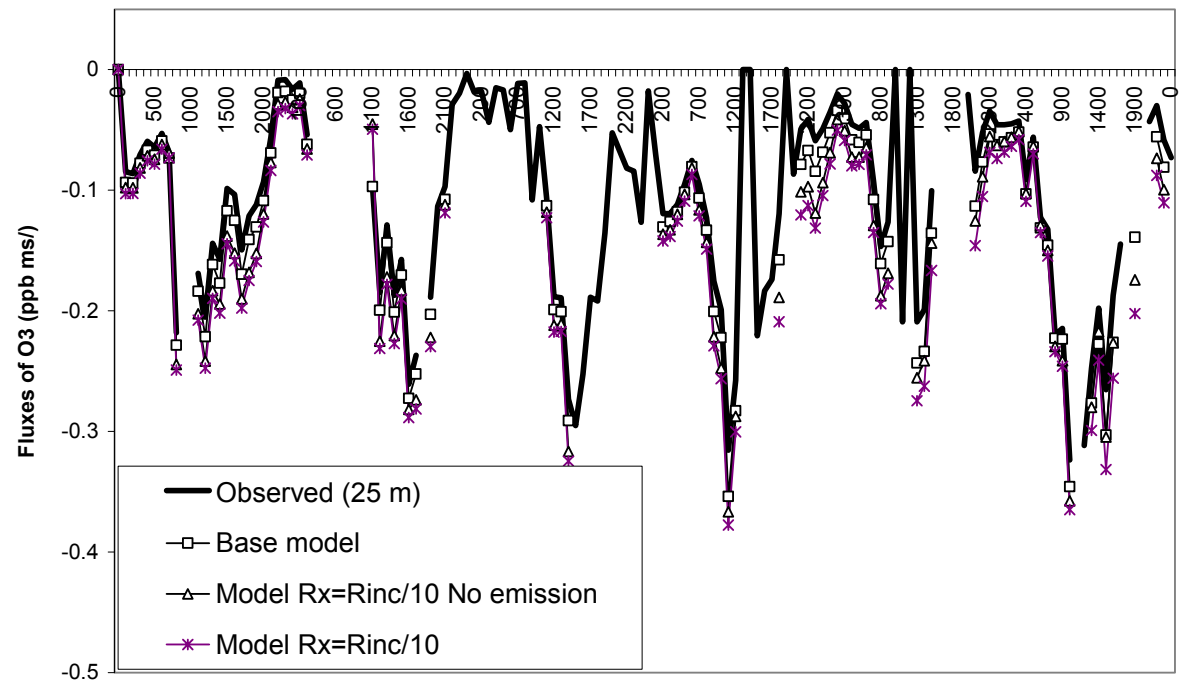

A simple model for air-forest exchange of $\mathrm{NO}_{\mathrm{x}}$ and $\mathrm{O}_{3}$

J. Duyzer et al.

\section{Title Page}

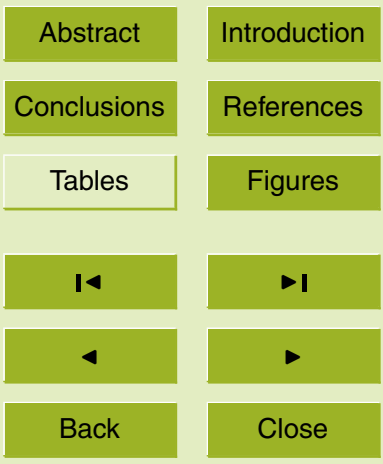

Fig. 7. The flux of $\mathrm{O}_{3}$ above Speulderbos and the flux calculated with the model using different parameters when running the model.

Full Screen / Esc

Print Version

Interactive Discussion

EGU 
BGD

2, 1033-1065, 2005

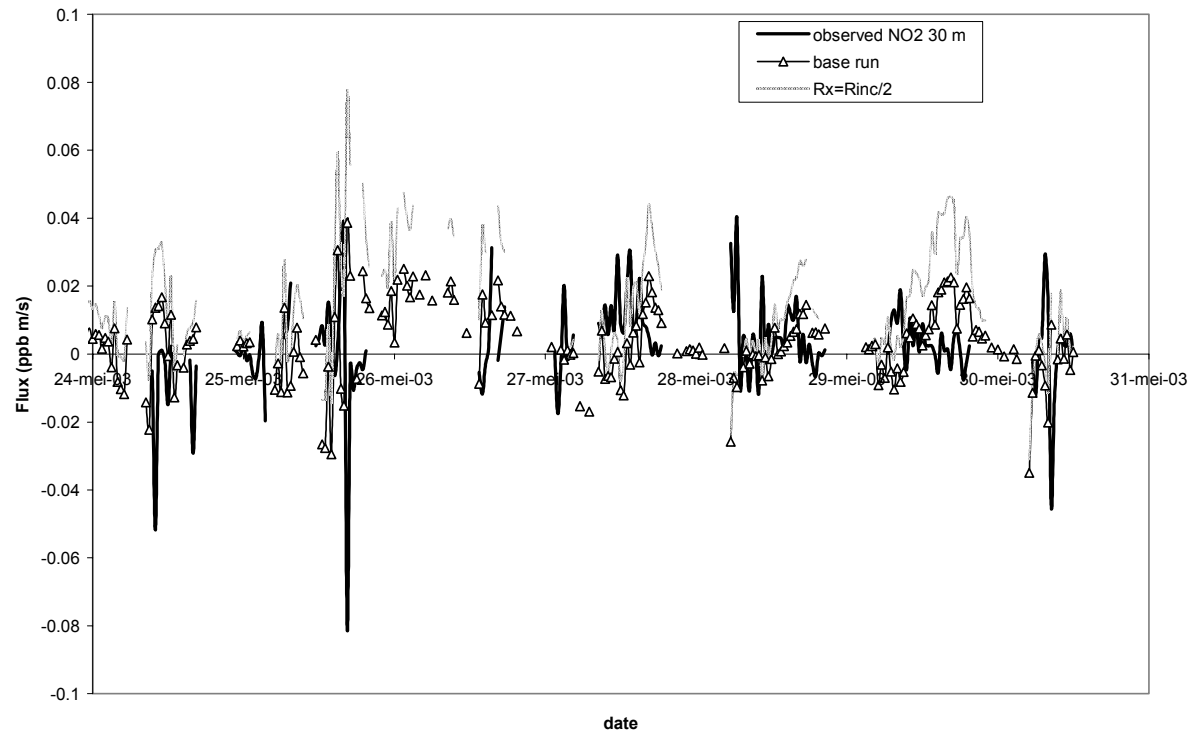

A simple model for air-forest exchange of $\mathrm{NO}_{\mathrm{x}}$ and $\mathrm{O}_{3}$

J. Duyzer et al.

\section{Title Page}

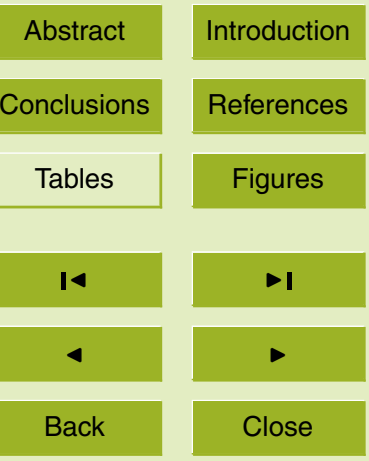

Fig. 8. The flux of $\mathrm{NO}_{2}$ above Soroe and the flux calculated with the 2layer model using different parameters when running the model.

Full Screen / Esc

Print Version

Interactive Discussion

EGU 
BGD

2, 1033-1065, 2005

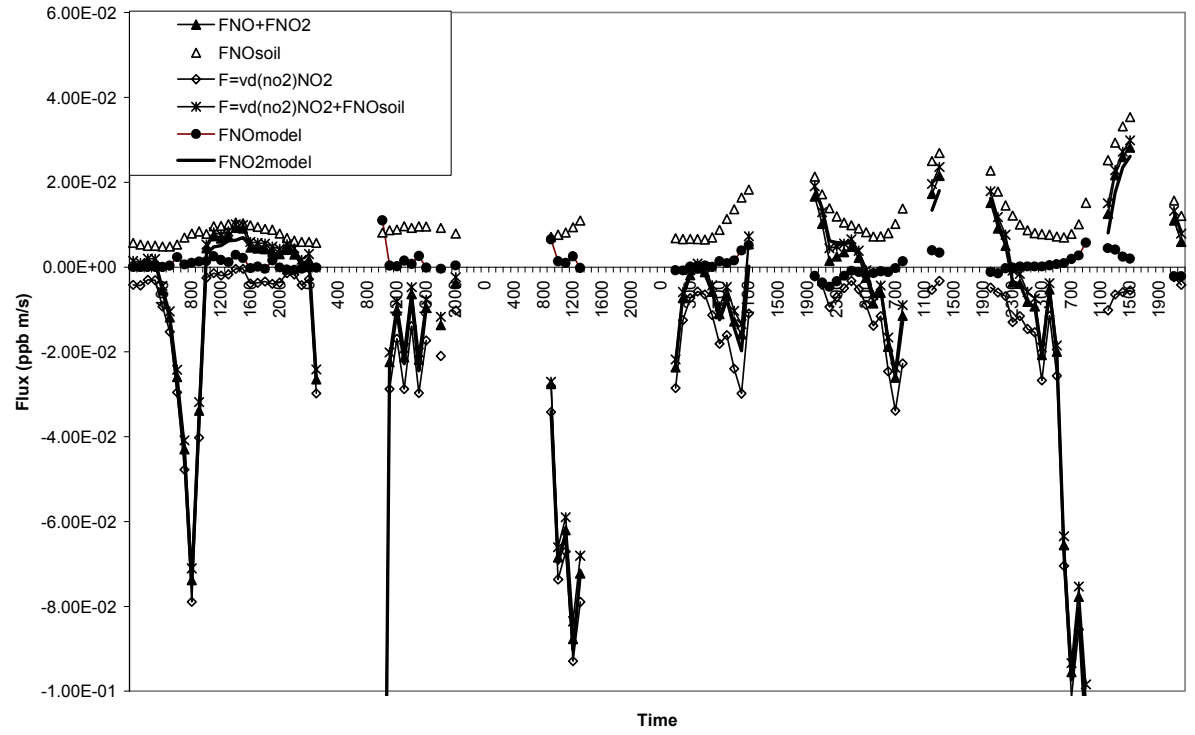

A simple model for air-forest exchange of $\mathrm{NO}_{\mathrm{x}}$ and $\mathrm{O}_{3}$

J. Duyzer et al.

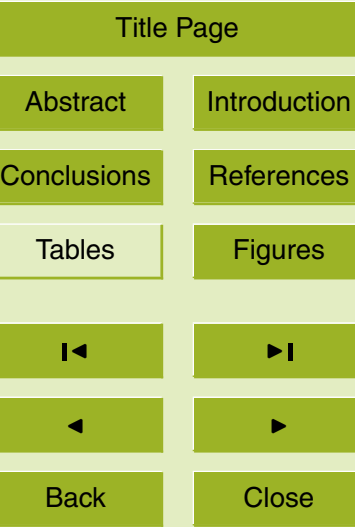

Fig. 9. Fluxes of $\mathrm{NO}_{2}$ and $\mathrm{NO}$ to Speulderbos calculated using the 2layer model using various methods to calculate the flux of nitrogen.

Full Screen / Esc

Print Version

Interactive Discussion

EGU 
Effect on ozone fluxes

(Speuld 1993)

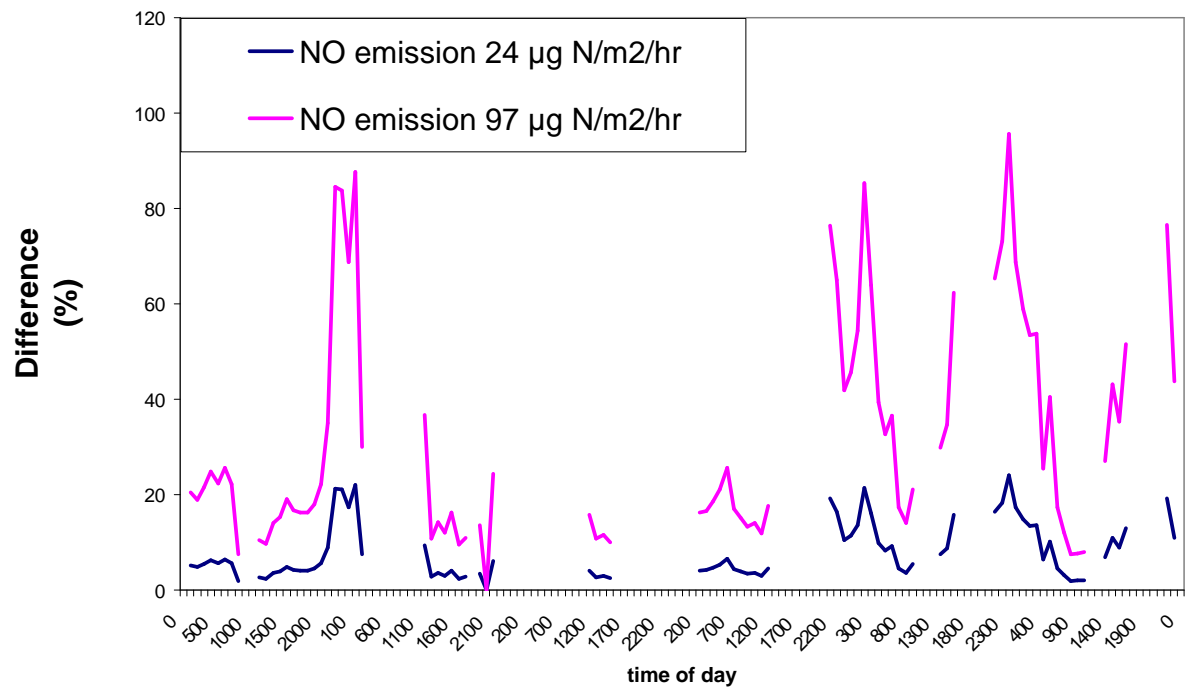

Fig. 10. The effect of the canopy processes on the deposition velocity of $\mathrm{O}_{3}$ for different emission rates of of NO from the forest floor in Speulderbos during the experiment in 1993. The difference with the flux with no emission of NO is presented.
A simple model for air-forest exchange of $\mathrm{NO}_{\mathbf{x}}$ and $\mathrm{O}_{3}$

J. Duyzer et al.

\section{Title Page}

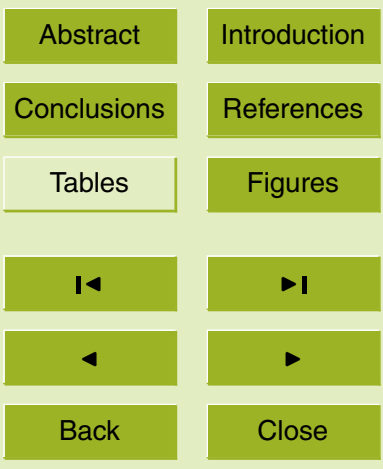

Full Screen / Esc

Print Version

Interactive Discussion 
Effect on ozone fluxes (Soroe 2003)

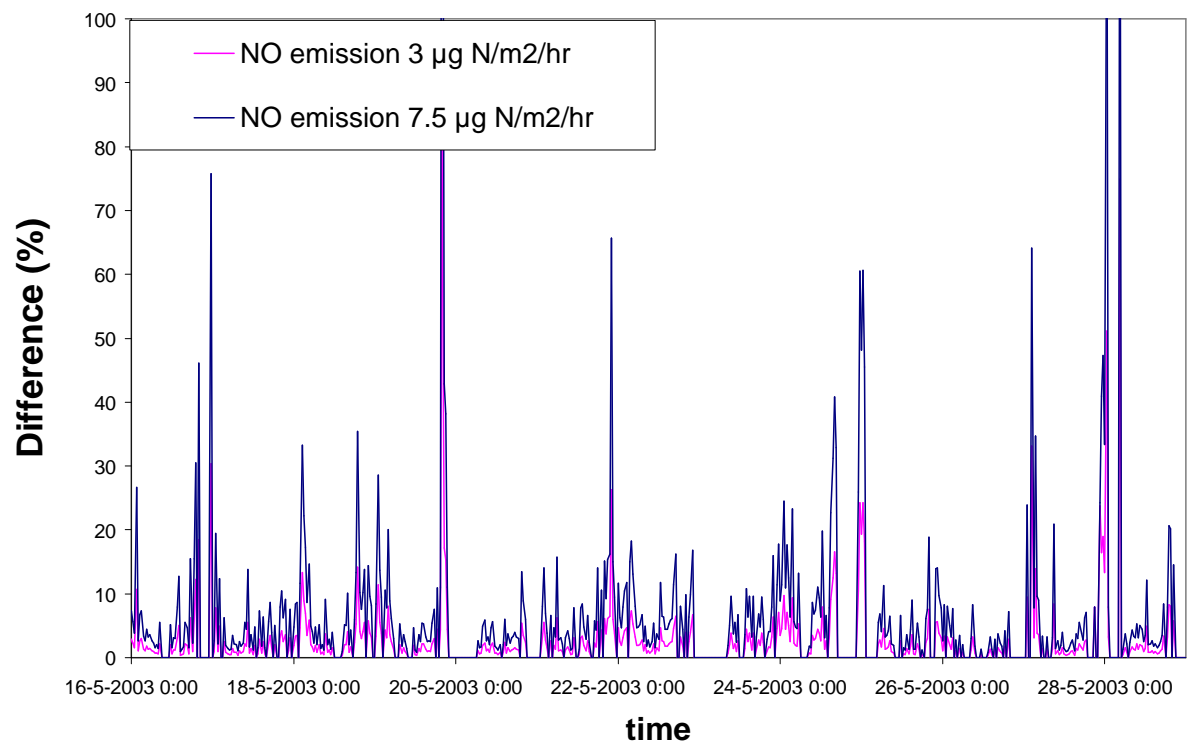

Fig. 11. The effect of the canopy processes on the deposition velocity of $\mathrm{O}_{3}$ for different emission rates of $\mathrm{NO}$ from the forest floor in Soroe in 2003. The difference with the flux with no emission of $\mathrm{NO}$ is presented.
A simple model for air-forest exchange of $\mathrm{NO}_{\mathbf{x}}$ and $\mathrm{O}_{3}$

J. Duyzer et al.

\section{Title Page}

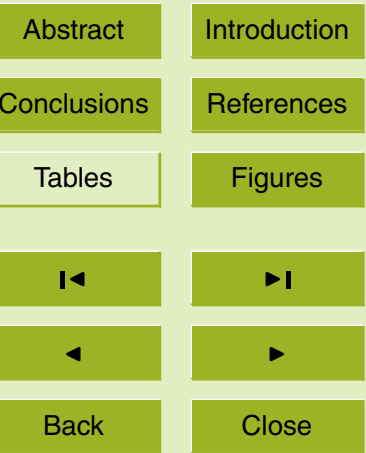

Full Screen / Esc

Print Version

Interactive Discussion 